\title{
Comparative carpological study of Poikilospermum (Urticaceae) in relation to taxonomy
}

\author{
T. I. Kravtsova ${ }^{1}$, A. Moore ${ }^{2}$ (D, C. M. Wilmot-Dear ${ }^{2}$ \& N. A. Zhinkina ${ }^{3}$
}

Summary. Fruit morphology and the anatomical structure of the pericarp, fruiting perianth, and seed coat were studied in 15 species of Poikilospermum, a genus whose position within the Urticaceae has long been controversial. Possible evolutionary trends of their transformation are suggested for both subgenera; plesiomorphies were found in P. oblongifolium and P. scabrinervium. Structural peculiarities of the fruit connected with its ejection out of the tubular perianth are discussed. The archaism of the fruit in Poikilospermum is revealed, indicated, as in Boehmeria, by the presence of the rudiment of an aborted carpel in the form of a large two-lobed rib. Using carpological anatomical characters, the species studied are classified into informal groups, such characters being able to pull the species within the subgenera into rough groupings where gross morphology has been unable to do so. It is shown that heterobathmy may be strongly associated with the genus Poikilospermum. Each subgenus has its own set of primitive carpological characters: in subgenus Poikilospermum the absence of a fruiting perianth which encases the fruit, and also of capitate inflorescences with swollen receptacles; in subgenus Ligulistigma remnant rudiment of the second carpel and ovary loculus, as well as a primitive, less simplified seed coat. Though the position of Poikilospermum as indicated by molecular data is within Urera, our results suggest that Dendrocnide (the only genus of the Urticeae that has a pyrenarium fruit type) may be closest to Poikilospermum, although the pericarp structure and dissemination behaviour in Poikilospermum are more specialised than those exhibited by Dendrocnide. Seed coat structure is also shown to exhibit traits seen in Moraceae.

Key Words. dispersal, evolution, fruit and seed anatomy, taxonomy, Urticeae.

\section{Introduction}

The genus Poikilospermum Zipp. ex Miq., found in Indo-Malesian regions of the Old World tropics, numbers approximately 20 species (Chew 1963). It is interesting in relation to its uncertain systematic position, unusual habit (hemi-epiphytic woody scramblers) and certain unusual mechanisms for dissemination. A combination of characters from both Urticaceae and Moraceae has been noted in Poikilospermum (for instance, Chew 1963; Grudzinskaya 1980). Moraceous traits are found mainly in the structure of vegetative organs, whereas Urticaceous ones are found in reproductive organs. Nevertheless, among the reproductive parts there are also characters in accord with Moraceae: erect filaments of stamens in bud (in subgenus Ligulistigma), swollen peduncular receptacles similar to those of Artocarpus and mucilage localisation in the mesocarp instead of the exocarp (Berg 1977, 1978; Kravtsova 1995). C. C. Berg (1978) included the genus
Poikilospermum in the new family Cecropiaceae C.C.Berg, intermediate between Urticaceae and Moraceae, where it occupied an isolated position. More recently, molecular data (Monro 2006; Hadiah et al. 2008; Wu et al. 2013; Kim et al. 2015) has confirmed the opinion of many authors (Weddell 1856 - 1857; Winkler 1922; Chew 1963; Wang \& Chen 1995; Chen et al. 2003) that its position should lie within the Urticaceae. However, even with the addition of such molecular evidence it has still proved difficult to find a place for the genus within this family. According to macromorphological traits it is placed in the tribe Boehmerieae (e.g. Weddell 1856; Wang \& Chen 1995; Chen et al. 2003); by wood anatomy it is similar to genera from different tribes - Nothocnide (Boehmerieae) and Urera (Urticeae); by the anatomical structure of the leaves it is close to the tribes Urticeae and Lecantheae (Bigalke 1933) and by the results of molecular systematics to either the clade uniting Lecantheae and Urticeae (Monro 2006), to

Accepted for publication 30 October 2019. Published online 29 April 2020

1 Laboratory of Plant Anatomy and Morphology, Komarov Botanical Institute RAS, Prof. Popov Street, 2; 197376 St., Petersburg, Russia. e-mail: kraveleon@yandex.ru

2 Herbarium, Royal Botanic Gardens, Kew, Richmond, Surrey, TW9 3AE, UK. e-mail: a.moore@kew.org; m.thomas@kew.org

3 Laboratory of Plant Embryology and Reproductive Biology, Komarov Botanical Institute RAS, Prof. Popov Street, 2; 197376 St., Petersburg, Russia. 
the Urticeae (Hadiah et al. 2008) or to the genus Urera (Wu et al. 2013; Kim et al. 2015). The results of $\mathrm{Wu}$ et al. (2013) whilst showing that Poikilospermum is nested within Urera, concluded that further research on generic relationships within this morphologically variable clade (Clade $3 \mathrm{~F}$ ) is needed. Maximumparsimony and maximum-likelihood approaches (Wu et al. 2015) suggest reversions of two characters in Poikilospermum: namely the loss of stinging hairs and the change from "oblique" achenes to straight ones.

In fruits of many Urticaceae species two sides of the ovary grow unequally; as a result, the style becomes displaced to the side of one of the two marginal ribs of the laterally flattened fruits (Fig. 14D, F). H. A. Weddell (1856 - 1857) used the term "oblique" to describe such fruits. Quite often the fruit stipe has also moved to the same side (Fig. 14F). The character of straight or oblique achenes was used to delimit genera within the tribe Urticeae (Weddell 1856 - 1857; Friis 1993; Deng et al. 2013). It was later shown that in the Urticaceae and allied families the fruit are pseudomonomerous, two-carpellate, the sterile carpel being more or less suppressed (Bechtel 1921; Eckardt 1937; Berg 1989). The existence of this suppressed carpel, sometimes supplied with a dorsal vascular bundle (Fig. 16B), largely explains the development of oblique fruits.

Poikilospermum fruits in much of the existing literature are termed achenes, sometimes drupaceous (Berg 1989). According to other classifications (for example, Bobrov et al. 2009; Kravtsova 2009) this fruit is a coenocarpous pseudomerous pyrenarium, similar to an apocarpous drupe in general pericarp arrangement. The ovule is single, orthotropous and bitegmic with only the outer integument being involved in seed coat formation. The tubular perianth of hypogynous female flowers grows after flowering, and the presence of a persistent fruiting perianth allows these fruits to be classified as anthocarpous fruits, namely drupe-like anthocarps, partly (subgenus Poikilospermum) or wholly (subgenus Ligulistigma) covered with a free, more or less fleshy and enlarged fruiting perianth. In subgenus Ligulistigma the fruits are aggregated into dense, capitulate infructescences uniting morphological traits of both sorosis (a dense aggregation of many fleshy fruits, Spjut 1994) and glandosum (an aggregation of fruitlets on a swollen peduncular receptacle). G. Bargagli-Petrucci (1902) and W.-L. Chew (1963) (quoting an apparent observation by E. J. H. Corner in Java in 1959) observed the ejection of fruits from the perianth in species of subgenus Ligulistigma, a phenomenon also mentioned by C. C. Berg (1977). The mechanism of ejection was however interpreted differently: either due to the inner perianth surface becoming mucilaginous at fruit maturity (Bargagli-Petrucci 1902) or by the basal thickening of the fruiting perianth (Berg 1977). Another peculiarity of the fruit is its easy separation into two apical valves (Trécul
1847; Chen et al. 2003) which does not occur in other representatives of the Urticaceae and allied families.

Comparative carpological studies of Urticaceae (Kravtsova 2001, 2003, 2009; Kravtsova et al. 2000, 2003) have revealed a set of characters with taxonomic significance in the family. Within fruit and seed morphology, the anatomical structure of the pericarp, of the seed coat and of the fruit accessory envelope (when structured) are all important. Pericarp structure is most important in studying systematics of taxa at various levels, especially the number of cell layers, differentiation into anatomical-topographical zones, the presence or absence of highly specialised cells, often mineralised, their structure and location. The seed coat has been found to be more conservative within the Urticaceae than the pericarp, it characterises the tribes or large groups within a tribe. These characters were thus selected here to examine Poikilospermum.

Carpological studies of Poikilospermum have hitherto only been concerned with a small number of species (Kravtsova 1995, 2003, 2009; Kravtsova et al. 2011) whilst brief mention on the subject is available in several articles by C. C. Berg $(1977,1978)$. Such studies have demonstrated that Poikilospermum is not closely related to other genera of the Cecropiaceae, but resembles, to some extent, certain species of Dendrocnide (tribe Urticeae) which maintain several archaic carpological traits.

The present comparative carpological study, carried out in connection with a taxonomic revision of the genus, has several aims: 1) to obtain more and broader information on Poikilospermum fruit and seed structure, with the inclusion of more species under study than in earlier work; 2) to reveal for the genus new, taxonomically important, carpological characters and to determine their possible evolutionary trends; 3) to discuss taxonomic problems of Poikilospermum according to the results of the present comparative carpological study; 4) to contribute to the resolution of the relationship between Poikilospermum and related (according to molecular data) genera of the Urticaceae; 5) to determine structural peculiarities of Poikilospermum fruits connected with dissemination.

\section{Material and Methods}

Fruit structure in 15 species from both subgenera, Poikilospermum and Ligulistigma was examined using light and scanning electron microscopes. The study was based on fruits from herbarium collections from $\mathrm{K}, \mathrm{L}, \mathrm{LE}$, and one spirit sample from L.

\section{Specimens investigated}

Subgenus Poikilospermum

P. acuminatum (Trécul.) Merr.: Philippines, 15 Nov. 1996, Reynoso Ẽ Majaducon PPI27069 (K). 


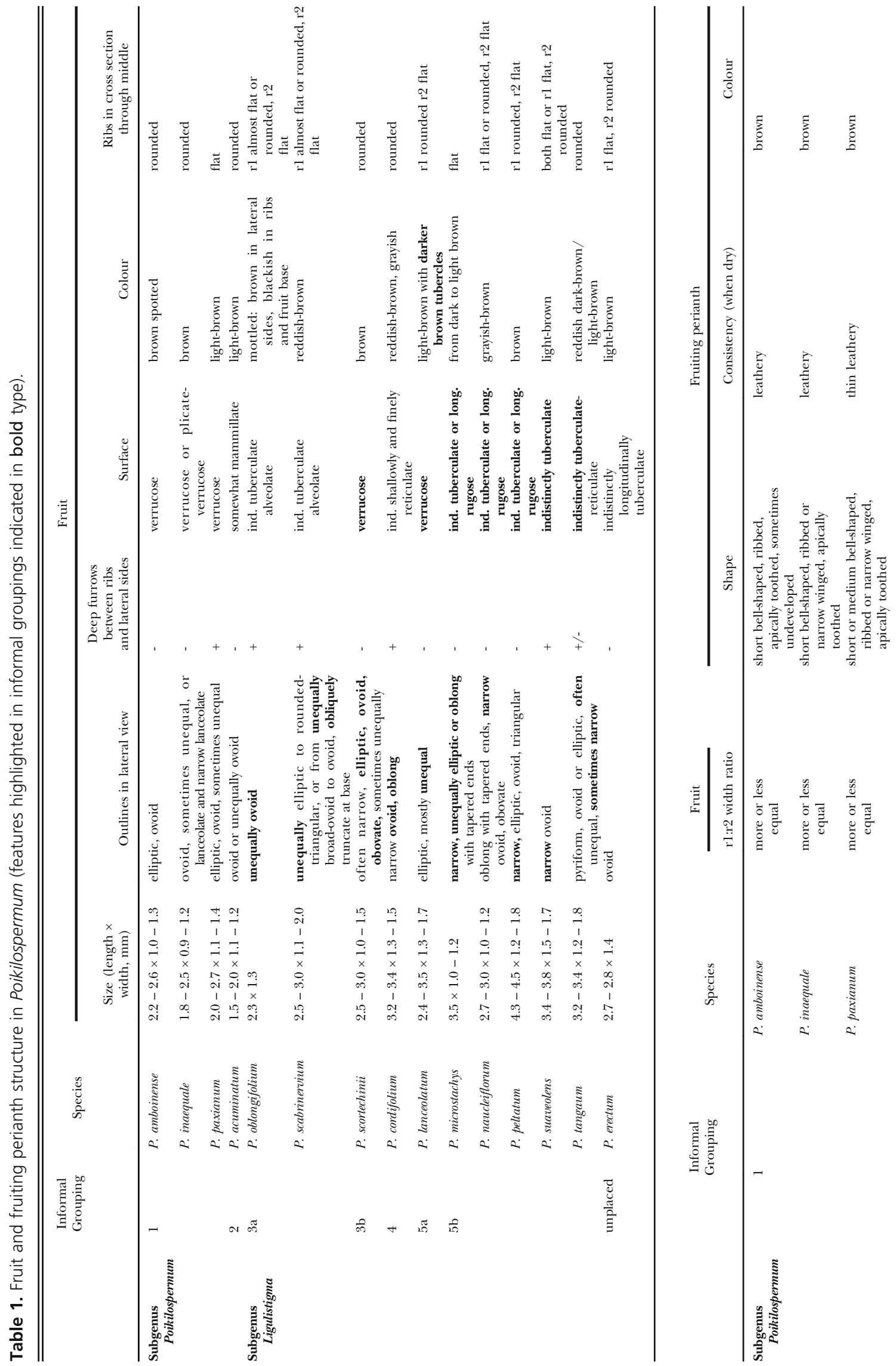




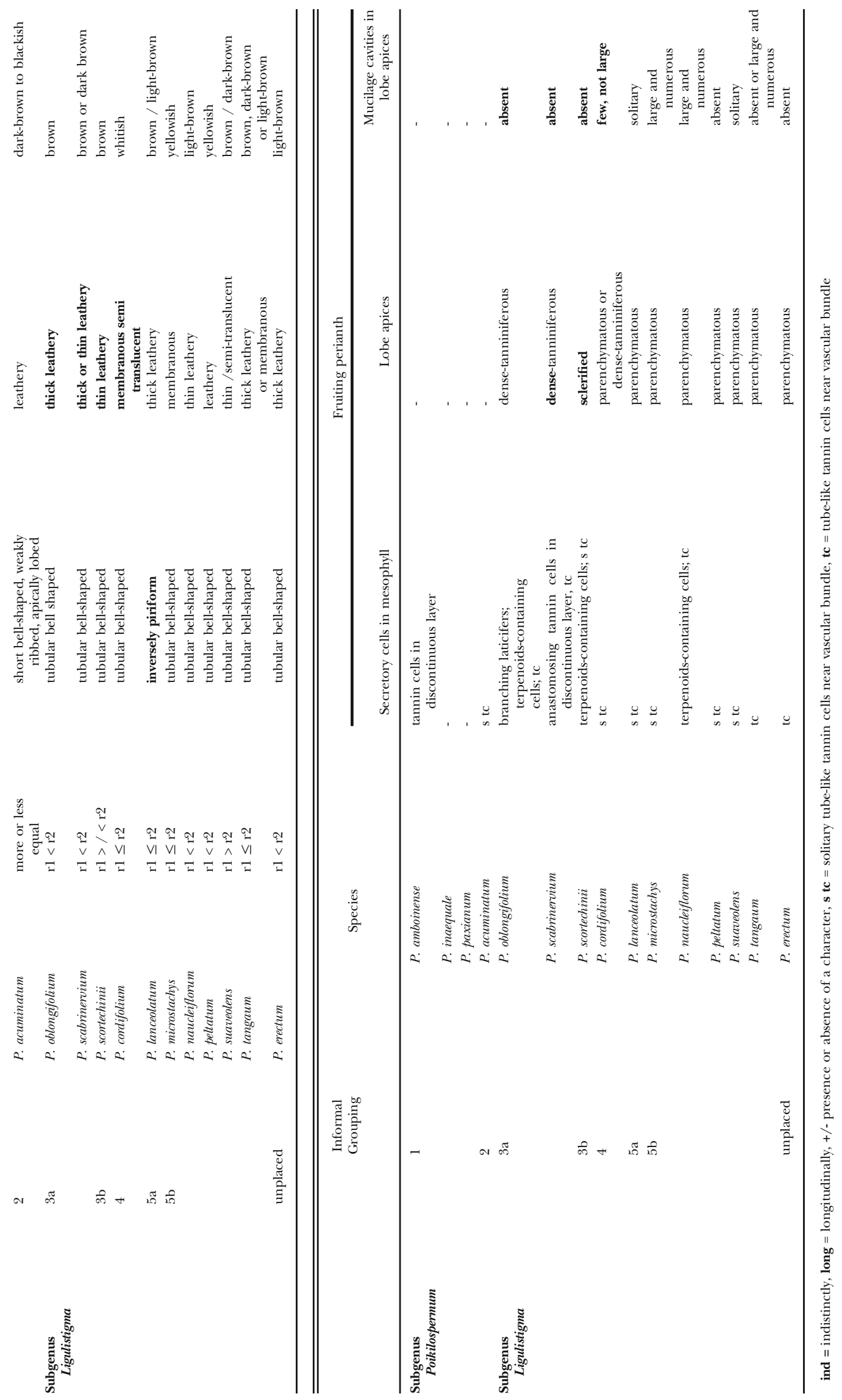


P. amboinense Zipp. ex Miq.: Moluccas, Ceram, 30 March 1991, J. S. Burley 4353 (K); Papua New Guinea, Pulsfford 5411 (K); New Guinea, Forbes 685 (LE).

P. inaequale Chew: Papua New Guinea, Koitaki, 29 April 1935, C. E. Carr 12079 (K); Papua New Guinea, Morobe Prov., Nov. 1963, J. S. Womersley NGF 17804 (K); West Papua, Mount Jaya, 7 April 2000, T. M. A. Utteridge 306, (K).

P. paxianum (H.J.P.Winkl.) Merr.: West Papua, Mount Jaya, 13 Nov. 2000, T. M. A. Utteridge 451 (K); Papua New Guinea, Kikori, 19 Aug. 1975, M. J. S. Sands et al. $1395(\mathrm{~K})$.

Subgenus Ligulistigma

P. cordifolium (Barg.-Petr.) Merr.: Borneo, Mt Kinabalu, 4 March 1961, W. L. Chew 266 (K); Borneo, Sarawak, 24 April 1983, D. Awa E I. S. Paie 45767 (K).

P. erectum (Blanco) Merr.: Philippines, Sept. 1912, Elmer 13901 (K).

P. lanceolatum (Trécul) Merr.: India, Sikkim, s. coll. s.n. (K).

P. microstachys (Barg.-Petr.) Merr.: Borneo, Kalimantan, 25 Sept. 1948, M. Enoh 309, (K); Malesia, Brunei, Corner 5369 (LE).

P. naucleiflorum (Roxb. ex Lindl.) Chew: Thailand, Khlong Phanom NP, 8 May 2006, S. Gardner; P. Sidisunthorn ST2707 (K).

P. oblongifolium (Barg.-Petr.) Merr.: Borneo, Sabah, 16 March 2002, S. Diwol E T. Tawadong, SAN 144311 (K).

P. peltatum (H.J.P.Winkl.) Merr.: Borneo, Vogel 841, Nat. Herbarium of the Netherlands, "Spirit collection" N 8356 (L)

P. scabrinervium (Barg-Petr.) Merr.: Brunei, 25 June 1989, K. M. Wong WKM1285 (K); Borneo, Mt Kinabalu, 29 Sept. 1931, Clemens 26631 (K).

P. scortechinii (King) Merr.: Malaysia, Johor, 26 June 1959, Kadim E M. Noor 199 (K).

P. suaveolens (Blume) Merr.: Malaysia, Trengganu, 30 March 1957, W. L. Chew 79 (K); Brunei, 28 May 1988, K Mat Salleh KMS 2420b (K).

P. tangaum Chew: Borneo, Mt Kinabalu, 26 May 1932, Clemens 29769 (K); Brunei, 4 April 1993, M. J. E. Coode 7622 (K).

Other Urticaceae

Dendrocnide meyeniana (Walp.) Chew f. meyeniana: Philippines, M. D. Sulit 11692 (L).

Dendrocnide stimulans (L.f.) Chew: Siam, A. F. G. Kerr 7811 (K).

Urera baccifera (L.) Gaudich. ex Wedd.: greenhouses in Komarov Botanical Institute RAS (St. Petersburg).

Dry and soaked fruits were observed and photographed using Stereomicroscopes Stemi-2000
CS and SteREO Lumar.V12 (Carl Zeiss, Germany). For anatomical study, fruits were first softened in a mixture of water, $96 \%$ ethanol and glycerol in equal proportions. Several histological techniques for their sectioning were used. Material was either used fresh or fixed in $70 \%$ alcohol and, for semi-thin sections, in $3 \%$ glutaraldehyde and 2\% Osmium tetroxide. Cross sections of fresh material 12 and $24 \mu \mathrm{m}$ thick were made in the middle part of fruits using a freezing microtome, and histochemical studies were carried out to determine lignin (with phloroglucinol and sulphuric acid), cutin (with Sudan IV), terpenoids (NADI test, according to David \& Carde 1964). Paraffin sections (12 $\mu \mathrm{m}$ thick, stained with gentianviolet and orange or Safranin in combination with alcian blue) were made on a rotary microtome following standard procedures (Prozina 1960), and semi-thin sections $(2-3 \mu \mathrm{m}$ thick, stained with toluidine blue) of material embedded in EponAraldite epoxy resin were prepared on a Reichert Ultracut R ultramicrotome. Observations were carried out, and photomicrographs were taken using light microscope AxioImager A1 (Carl Zeiss). A scanning electron microscope Jeol JSM-6390 LA (the equipment of Core Centre "Cell and Molecular Technology in the Plant Science" at the Komarov Botanical Institute, St. Petersburg) was used to investigate the external morphology of the fruits, seeds, and their internal structure.

This paper follows the terminology of I. Roth (1977) and E. J. H. Corner (1976) in describing the pericarp and seed coat structure, respectively. Basic points for the description of plant surfaces, in particular seed surfaces, were published by R. M. Murley (1951), W. Barthlott \& N. Ehler (1977), W. Barthlott (1981), E. Werker (1997). The schematic drawings in Fig. 3 'longitudinal and cross sections of Poikilospermum fruit' provide further explanation of terminology used in this paper.

\section{Observations}

Poikilospermum fruits (Fig. 1A - S, 2A - M) are usually described as straight, but the style is often somewhat displaced to either rib, likewise the stipe, where present, may also be displaced to the side of the suppressed carpel as previously described, fruits thus often becoming inequilateral in lateral view and somewhat oblique in the sense of Weddell. In such inequilateral fruits the pericarp rib formed by the fertile carpel (r1) is more strongly curved and thus always longer than the rib from the suppressed carpel side (r2) and sometimes markedly more protruding. This is particularly evident in $P$. oblongifolium, $\mathrm{P}$. scabrinervium (Fig. 1H, 2D), and P. tangaum (Fig. 1K, 2J), where the style is centred at the top of the fruit or slightly displaced towards the fertile side. In certain 

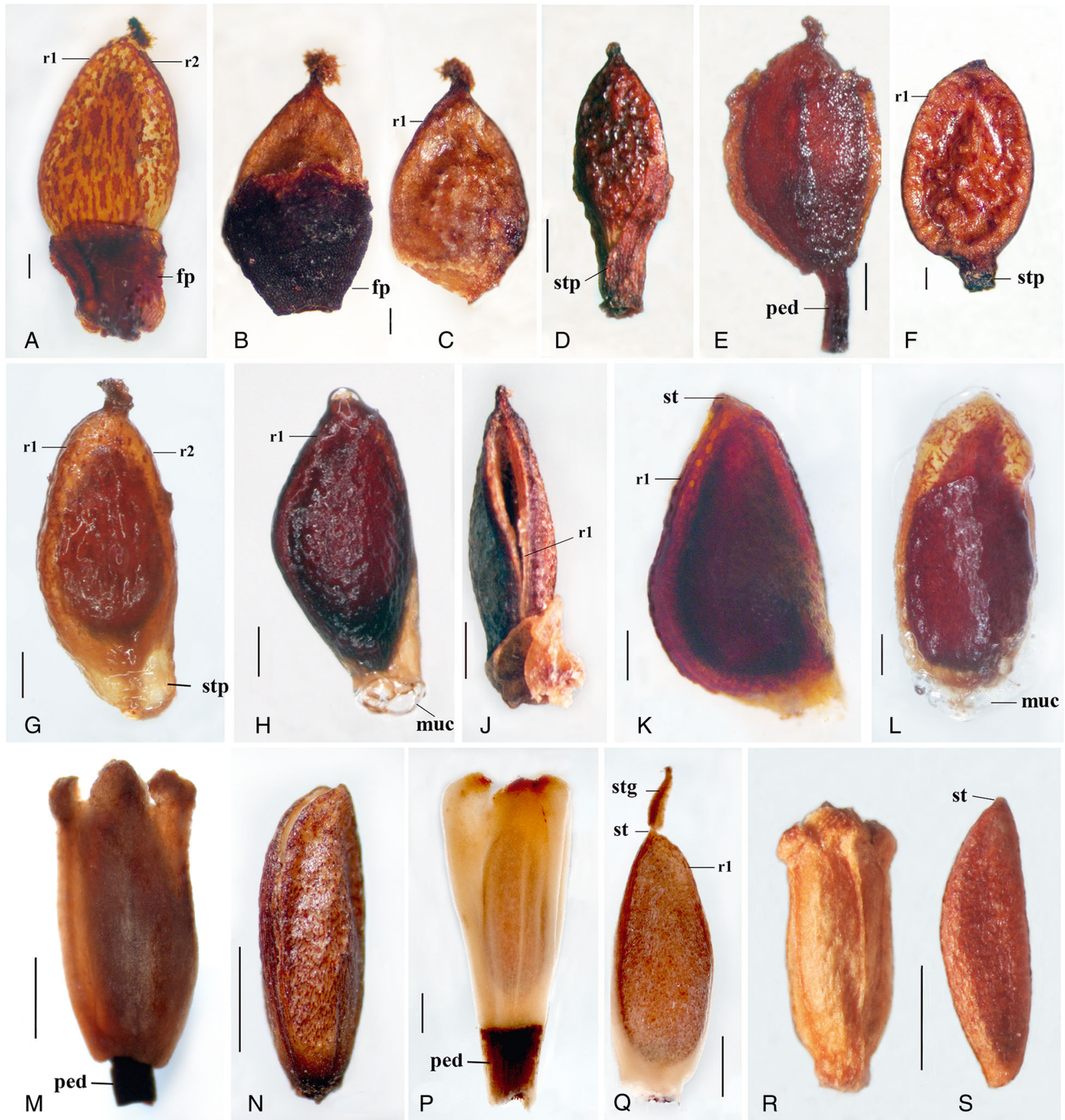

Fig. 1. Poikilospermum fruits. A $P$. amboinense, Pulsfford 5411; B, C $P$. acuminatum: B fruit enclosed in fruiting perianth, $C$ fruit without fruiting perianth; D P. inaequale, Carr 12078; E, F P. paxianum, Sands 1395; G P. lanceolatum; H, J P. scabrinervium, Wong WKM1285: $\mathrm{H}$ view from lateral side, J view from rib side; $\mathrm{K}$ P. tangaum, Clemens 29769; $\mathrm{L} P$. suaveolens; $\mathrm{M}, \mathrm{N}$ P. naucleiflorum; P, Q P. peltatum; R, S P. microstachys, M. Enoh 309; A, E, G, H, K - M, P, Q wet; B, C, D, F, J, N dry; fp fruiting perianth; muc mucilage; ped pedicel; $r 1$ pericarp rib from fertile carpel's side; $r 2$ pericarp rib from suppressed carpel's side; st style; stg stigma; stp stipe. Scale bars: $A-C, F=200 \mu m ; D, E, G-L=500 \mu m ; M-R=1000 \mu m$

species there may also be much variation in the degree of asymmetry in inequilateral fruits within a collection, sometimes within a species (e.g., in $P$. inaequale and P. microstachys - Fig. 1R, 2K, L).

Both subgenera of Poikilospermum have species with often clearly inequilateral fruits (e.g. P. acuminatum-
Fig. 1C, P. lanceolatum - Fig. 1G, P. scabrinervium, $P$. tangaum) and species with mainly more or less symmetric fruits (e.g. P. peltatum - Fig. 1Q, P. suaveolens - Fig. 1L, P. erectum).

Morphological and anatomical carpological features are described in detail in Tables $1-3$. 

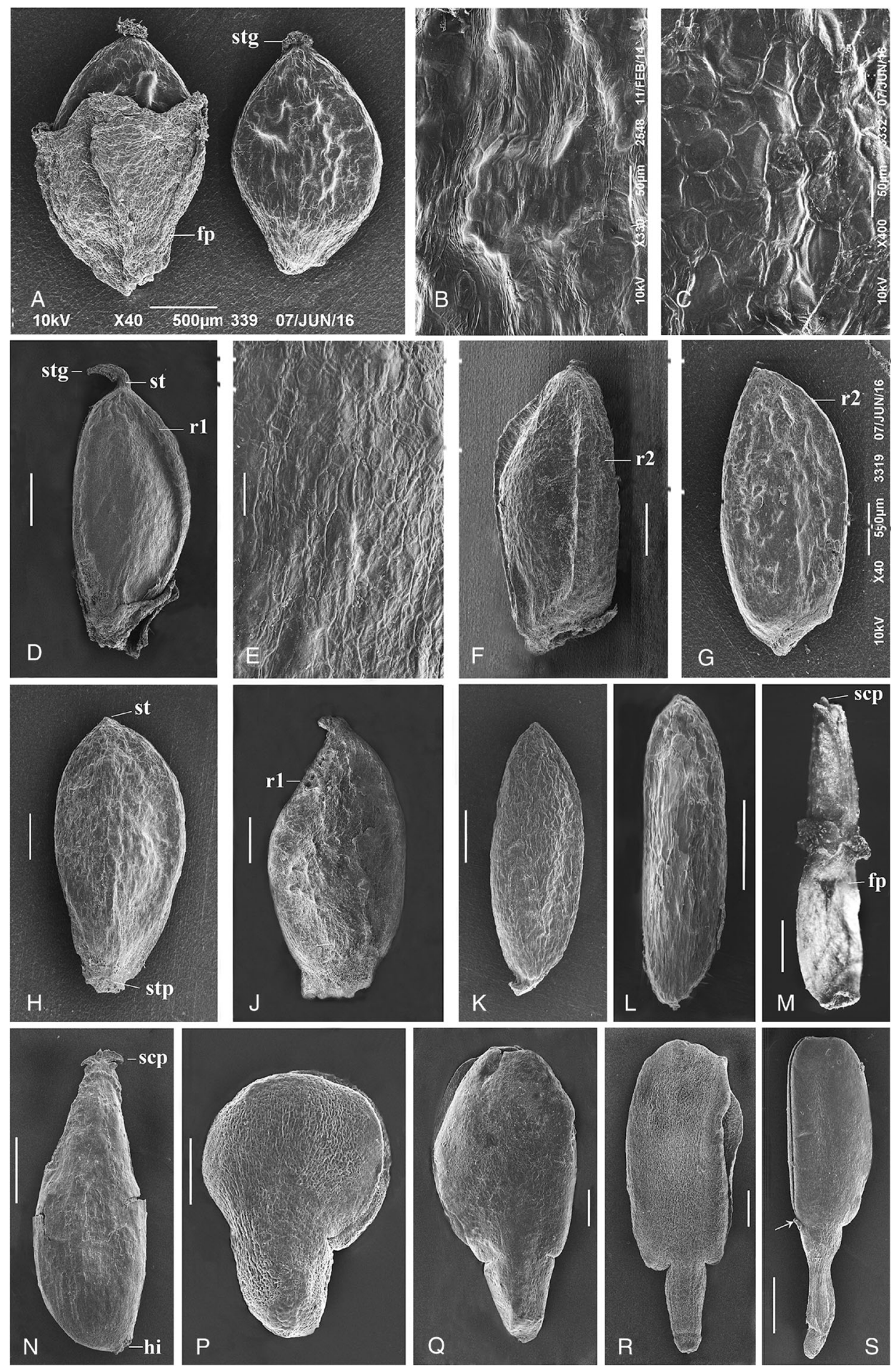

Fig. 2. SEM micrographs of fruits, seeds and embryos. A - M fruits: A Poikilospermum inaequale, Utteridge 306: fruit enclosed in fruiting perianth and devoid of it; B $P$. inaequale, Carr 12079, fruit surface on lateral side; C $P$. paxianum, Utteridge 451, fruit surface on lateral side; D, E P. scabrinervium, Wong KM1285 (D fruit, E its surface on lateral side); F $P$. scabrinervium, Clemens 26631, rib from suppressed carpel's side is shown; G P. scortechinii; H P. lanceolatum; J P. tangaum, Clemens 29769; K - M P. microstachys: K M. Enoh 309, L, M Corner 5369 (K, L fruit, M fruit squeezed out of fruiting perianth, from herbarium specimen); $\mathrm{N}$ seed, P. naucleiflorum; $\mathrm{P}-\mathrm{S}$ embryos ( $\mathrm{P}, \mathrm{S}$ not completely mature): $\mathrm{P}$ P. amboinense, Pulsfford 5411; Q P. scabrinervium, Clemens 26631, R P. peltatum; S P. microstachys, Corner 5369; fp fruiting perianth; hi hilum; $r 1$ pericarp rib from fertile carpel's side; $r 2$ pericarp rib from suppressed carpel's side; scp seed coat process; st style; stg stigma; stp stipe; arrow = processes at base of cotyledons. Scale bars: A, D, F - K, N, S = 500 $\mu \mathrm{m} ; \mathrm{B}, \mathrm{C}, \mathrm{E}=50 \mu \mathrm{m} ; \mathrm{L}, \mathrm{M}=1000 \mu \mathrm{m} ; \mathrm{P}=100 \mu \mathrm{m}, \mathrm{Q}, \mathrm{R}=200 \mu \mathrm{m}$ 


\section{Fruit Morphology - General Description}

(A) subgenus Poikilospermum

Table 1; Figs 1A - F, 2A - C. Fruits are small, laterally flattened with two more or less protruding ribs, apically slightly tapered, with a subsessile capitate stigma and (usually) a long stipe, subsessile or (in Poikilospermum paxianum only — Fig. 1E) distinctly pedicellate; the lateral sides generally have a verrucose surface and reticulate primary sculpture (Fig. 2B, C). In inequilateral fruits the persistent stigma and/or stipe are displaced to the $\mathrm{r} 2$, a feature not unusual in the Urticaceae (Fig. 14).

The gamophyllous fruiting perianth covers half the fruit or less, rarely more than half (Fig. 1E); it is 4ribbed or narrow wing-shaped (Fig. 1E), brown to blackish, with whitish cystoliths at the top.

(B) subgenus Ligulistigma

Table 1; Fig. 1G - S, 2D - M. Fruits are larger, laterally flattened, rarely cylindrical (sometimes in Poikilospermum microstachys), with well-developed ribs that are often wide, flat, rounded or, wedge-shaped in cross section, in several species isolated by furrows from the raised lateral fruit sides. They are slightly tapered at the apex, terminated by a persistent minute style (sometimes the ligulate stigma is also still present - Figs 1G, 2D), shortly stipitate or obliquely truncate at the base; the lateral sides are either indistinctly sculptured (Fig. 2D, 2J - M), or verrucose (Fig. 2G, H), sometimes with discernible reticulate primary sculpture (Fig. $2 \mathrm{E})$. In inequilateral fruits the style is displaced to r2 (P. lanceolatum - Fig. 1G), or to the longer, strongly curved $\mathrm{r} 1$ ( $P$. scabrinervium - Fig. $1 \mathrm{H}$, P. tangaum - Fig. 1K; P. oblongifolium).

In certain collections of some species (Poikilospermum cordifolium, P. microstachys, $P$. naucleiflorum) fruit dehiscence via two apical valves was noted (Fig. 1N, 2M), while in certain fruits of $P$. scabrinervium the dehiscence occurs via longitudinal splitting along r1 (Fig. 1J). However, in every species the extent of dehiscence was inconsistent throughout all material studied. Within the same species, fruits with ribs of both similar and dissimilar size are usually present. Especially marked variation is noted in $P$. scabrinervium and $P$. oblongifolium, where in inequilateral fruits, the short, right rib (r2) is wide and flat, the other (r1) is strongly curved, long, not always flat and possessing a filiform suture.

The persistent tubular perianth is predominantly bell-shaped, rarely inversely pyriform, varying in colour and texture between species (Table 1). It is thicker at the base and apex than in the middle (Fig. 3C), ribbed and often folded along and sometimes between the midribs. Swollen folds, particularly well developed in Poikilospermum peltatum (Fig. 3D), P. tangaum Clemens 29769 and P. scortechinii, promote considerable perianth thickening there, especially at the apices. Perianth tepals are usually strongly incurved, rarely slightly incurved ( $P$. naucleiflorum Fig. 1M). Round or oval to oblong cystoliths occur on the upper part of the perianth lobe; their size and shape appearing inconsistent within species.

\section{Stipe and Fruit Base}

In both subgenera the fruit stipe (through whose centre the vascular bundle runs to the seed) consists of two vertical zones (Fig. 3A - C). The upper zone is sclerenchymatous, formed by a central strand of sclereids, surrounded with mucilage cells, whereas the lower zone is formed mainly by mucilage cells. The sclerenchyma strand is situated asymmetrically, displaced towards the fertile carpel, whereas mucilage cells are more numerous on the reduced carpel side. Most species of subgenus Poikilospermum have a stipe with a long sclerenchyma zone (Fig. 3A, B); in subgenus Ligulistigma it is considerably reduced (Fig. 3C), sometimes forming folds in the fruit base.

\section{Seed}

Seeds are orthotropous, ovoid or narrowly ovoid (Fig. 2N, 3A - C). In subgenus Poikilospermum they are basally, or nearly basally, attached and smaller in size than in subgenus Ligulistigma (a factor of smaller fruit size combined with a large stipe which occupies considerable space within the anthocarp). In subgenus Ligulistigma the placentation is subbasal (Fig. 3C, 10F) and the seeds are thus asymmetrical at the base (Fig. 2N). In P. scabrinervium the stipe is obliquely angled and positioned on the r2 side, as is the placenta. The fertile carpel makes a depression on the opposite side where the seed "descends". This explains the narrowed tip of the cotyledons, and the extremely lateral position of the placenta in this species. The seed vascular bundle ascends within the placenta and then descends within the hypostase, making a loop; fairly long in P. naucleiflorum (Fig. 10F) and P. scabrinervium and short in $P$. peltatum (Fig. 3C). This terminates in the tanniniferous hypostase. Similar curvature of vascular strand to ovule was described in Boehmeria cylindrica by A. R. Bechtel (1921). Specific differences in placental position and the curvature of the seed vascular bundle in Poikilospermum require further study because there are large variations in fruit asymmetry even within the same collection.

In both subgenera the thin, tanniniferous seed coat is membranous or coriaceous; it forms wing-like extensions along the seed ribs in the upper seed part of subgenus Ligulistigma species (Fig. 10C), and flat projections of variable shape at the top (Fig. 2M, N), apparently derived from the integumental obturator. The endosperm is scarce (Fig. 3A - D) consisting of 3 -5 compressed layers in the middle part of the seed, 

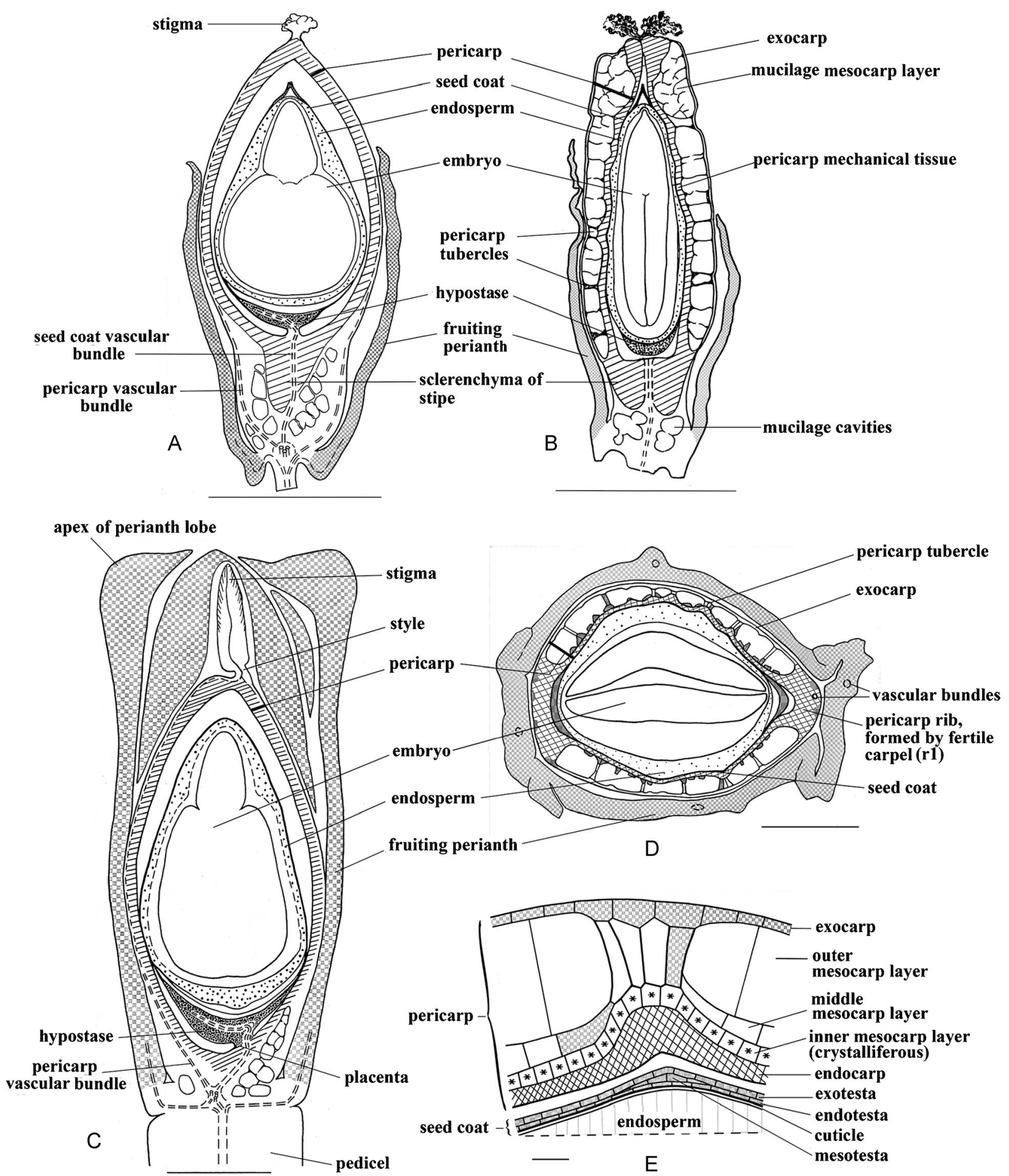

Fig. 3. Longitudinal and cross sections of Poikilospermum fruit. A longitudinal dorsiventral section of $P$. amboinense fruit; $\mathbf{B}$ longitudinal bilateral section of $P$. paxianum fruit, $C, D$. peltatum (pre-mature stage): $C$ longitudinal dorsiventral section; D cross section; E schematic drawing of pericarp tubercle; tannin cells are shaded. Scale bars: $A-C=1000 \mu \mathrm{m}, \mathrm{D}=500 \mu \mathrm{m}$

where it is thicker on the lateral seed sides, and is localised mainly along the seed ribs towards the apex.

The embryo (Fig. 2P - S, 3A-C) occupies almost the entire seed cavity; in subgenus Poikilospermum it is c. 0.8 -
$1.15 \mathrm{~mm}$, in subgenus Ligulistigma much longer, 1.6 $2.9 \mathrm{~mm}$ long. Cotyledons are plane-convex, their length usually exceeds the hypocotyl-root axis. The plumule has two minute leaf primordia. The embryos of different 
species differ in size, shape and degree of asymmetry, of cotyledons and hypocotyl-root axis length and width, their width being determined by the fruit shape. The degree of embryo asymmetry varies even within the same collection corresponding to the degree of asymmetry in the fruits. In $P$. microstachys two small processes (stipules or colleters?) were discovered at the base of the cotyledons (Fig. 2S, arrow).

\section{Fruiting Perianth Structure}

(A) subgenus Poikilospermum

The fruiting perianth is five to seven-layered, 20 $130 \mu \mathrm{m}$ thick, parenchymatous, containing tannins, mineral inclusions (cystoliths, crystals, druses of calcium oxalate) and sometimes mucilage within its tissues (Fig. $4 \mathrm{~B}, \mathrm{C}, \mathrm{E}-\mathrm{G}, \mathrm{J}$ ), the cystoliths are more or less numerous in the outer subepidermal layer of the apices.

Two structural types of fruiting perianth may be distinguished:

(i) Rather thick (70 - $130 \mu \mathrm{m}$ thick, especially in ribs) with a large content of tannins in both epidermal layers (Poikilospermum acuminatum Fig. 4C) or in the outer epidermis and one to two underlying mesophyll layers ( $P$. amboinense - Fig. $4 \mathrm{~B})$; the outer epidermis is large-celled, in $P$. acuminatum palisade-like with small crystals (like the inner epidermis); with occasional mucilaginous cavities occurring in the mesophyll.

(ii) Usually thin $(20-70 \mu \mathrm{m}$ thick), with strongly prominent ribs/wings up to 110 - $220 \mu \mathrm{m}$ in height, consisting of compressed, more or less thick-walled cells with a low content of tannins, predominantly in mesophyll cells - Poikilospermum inaequale (Fig. 4E, F), P. paxianum (Fig. 4G, J); in the outer epidermis are areas consisting of mucilage cells. In $P$. inaequale the fruiting perianth structure varies; in certain specimens it is similar to that of $P$. acuminatum.

\section{(B) subgenus Ligulistigma}

The enlarged tubular fruiting perianth is five to sevenlayered; 15 - $120 \mu \mathrm{m}$ thick, parenchymatous, formed by more or less thick-walled cells (Fig. 5A - F; 8A - D, F; 10A - D, F). Both epidermal layers are compressed, membranous, often tanniniferous (particularly the outer one), sometimes in places with mucilage cells in the outer epidermis (Poikilospermum cordifolium, $P$. lanceolatum, P. suaveolens). Mesophyll cells, with more or less tannin content (may vary between different collections of the same species) or without tannins, are compressed to different degrees or uncompressed, have irregularly thickened walls and often form collenchyma-like tissue. Cell content is more diverse than in subgenus Poikilospermum and includes an amorphous yellowish matter. Thickened, colourless cell walls in $P$. naucleiflorum (Fig. 5F),
P. oblongifolium, $P$. scabrinervium, $P$. scortechinii and P. tangaum Clemens 29769 are perhaps silicified. In the mesophyll of several species there are secretory cells of different types (Table 1): branching laticifers (Fig. 5A), uncompressed tannin cells, mainly tube-like, along with vascular bundles (Fig. 5C, 8A, B), terpenoid-containing cells, filled with yellowish latex $(5 \mathrm{~B}, \mathrm{~F})$, mucilage cells collected in the cavities in the apex of the lobes (Fig. 6C - E). Perianth ribs and ribbed folds along veins are strengthened by several mechanical elements, accompanying vascular bundles, among them druses and short thick-walled hairs in both epidermal layers.

The incurved pubescent apices of the fruiting perianth lobes differ in thickness and structure between species (Table 1; Fig. 6A - F). The outer epidermis, usually tanniniferous, is only slightly flattened (Fig. 6A, B) or is membranous and structureless when the tannin content is small. The cystoliths, situated in the outer subepidermis are usually numerous and clearly visible, but in Poikilospermum scortechinii they are small and scarce and irregularly shaped (Fig. 6B). The mesophyll is densely tanniniferous (Fig. 6A), sclerified (Fig. 6B), in most species parenchymatous (Fig. 6C - F); large mucilaginous cavities are absent, isolated, or large and numerous. Short, thick-walled hairs occur either in both epidermal layers (most abundant in P. cordifolium) or only in the inner epidermis ( $P$. scabrinervium, $P$. suaveolens).

\section{Pericarp Structure}

Exocarp structure in both subgenera is similar; onelayered, membraneous and composed of compressed polygonal tannin cells or cells without tannins or with only little amounts of tannin, rarely having isolated cells with mucilage (Fig. 4). The outer tangential wall varies in thickness between species (Table 2). Within the mesocarp three zones may be distinguished - outer mucilaginous, middle (parenchymatous in subgenus Poikilospermum, structurally diverse in subgenus Ligulistigma) and inner crystalliferous. Pericarp ribs are diverse in size and structure, formed by the folding of the pericarp (Table 1; Figs 3D; 8; 10).

\section{(A) Subgenus Poikilospermum}

The pericarp is folded, four to six-layered, with a rather thick folded endocarp and mucilage-containing mesocarp (Table 2; Fig. 4A - J). In marked contrast to subgenus Ligulistigma (see below), the mucilaginous layer is interrupted by wide endocarp folds causing mucilage cells to be located in some specimens in the areoles of the pericarp, separated by large endocarp folds and large tracts of tanniniferous mesocarp and exocarp tissues. Endocarp thickness, the degree of folding, tannin content and localisation, and the extension of the mucilaginous zone varies between but sometimes also within the same species 

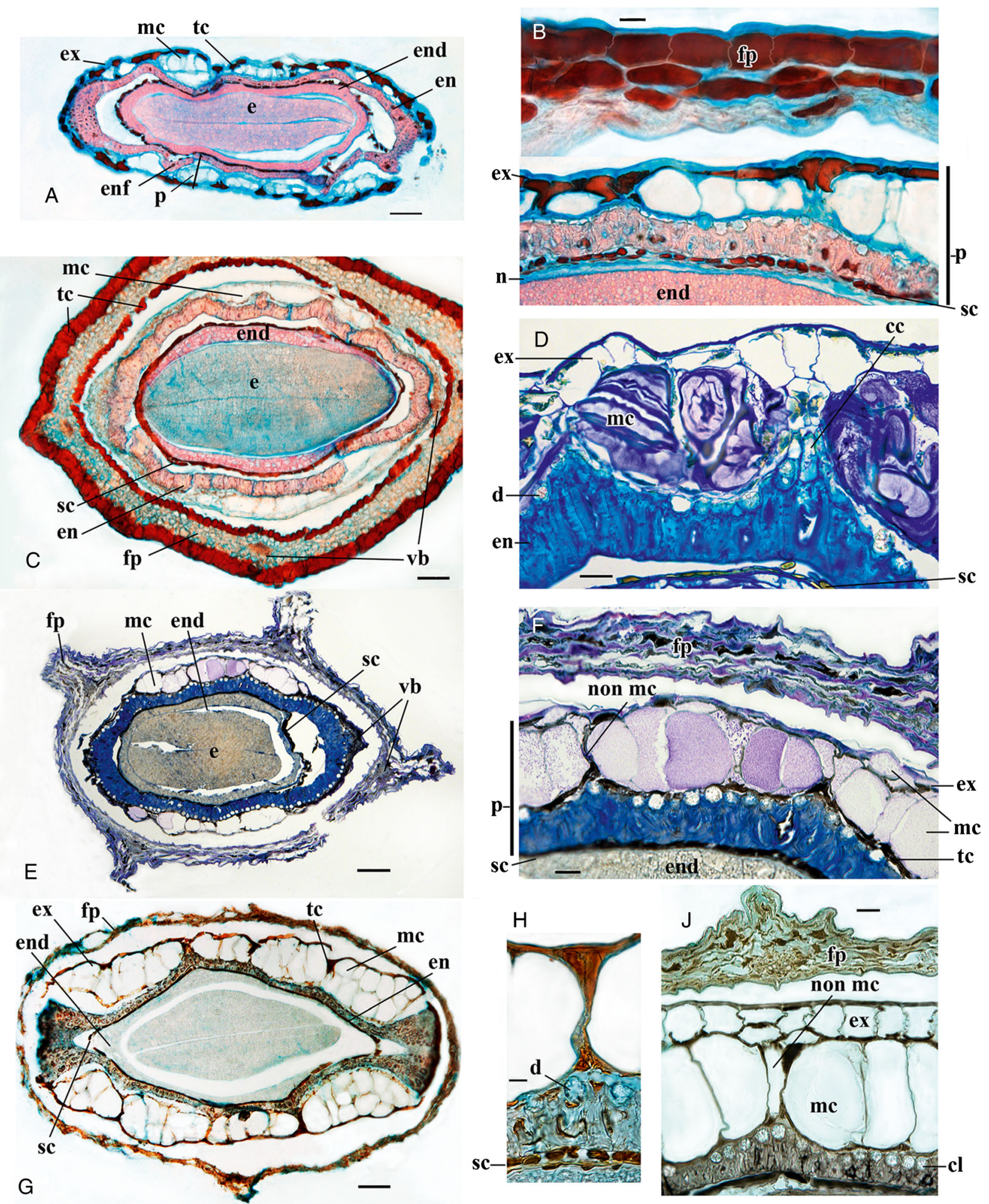

Fig. 4. Fruit and fruit wall in cross section; Poikilospermum subgenus Poikilospermum. A, B $P$. amboinense; C, D $P$. acuminatum;, $\mathrm{F} P$. inaequale; $\mathrm{G}-\mathrm{J} P$. paxianum. $\mathrm{A}, \mathrm{C}, \mathrm{E}, \mathrm{G}$ whole fruits (A without fruiting perianth); $\mathrm{B}, \mathrm{D}, \mathrm{F}, \mathrm{H}, \mathrm{J}$ portions of fruit wall: $\mathrm{B}, \mathrm{F}, \mathrm{J}$ fruiting perianth and pericarp; D, H pericarp. A - C, G - J stained with Safranin and alcian blue: tannins are red, mucilage colourless; D - F stained with toluidin blue: tannins are yellowish-brown, mucilage violet; cc crystal cell, cl crystal layer; $d$ druse of calcium oxalate; e embryo; en endocarp; end endosperm; enf endocarp fold; ex exocarp; fp fruiting perianth; mc mucilage cell; $\mathrm{n}$ nucellus (remnants); non mc cell without mucilage; $\mathrm{p}$ pericarp; sc seed coat; tc tannin cell; vb vascular bundle. Scale bars: $\mathrm{A}, \mathrm{C}, \mathrm{E}$, $\mathrm{G}=100 \mu \mathrm{m} ; \mathrm{B}, \mathrm{D}, \mathrm{F}, \mathrm{J}=20 \mu \mathrm{m} ; \mathrm{H}=10 \mu \mathrm{m}$ 

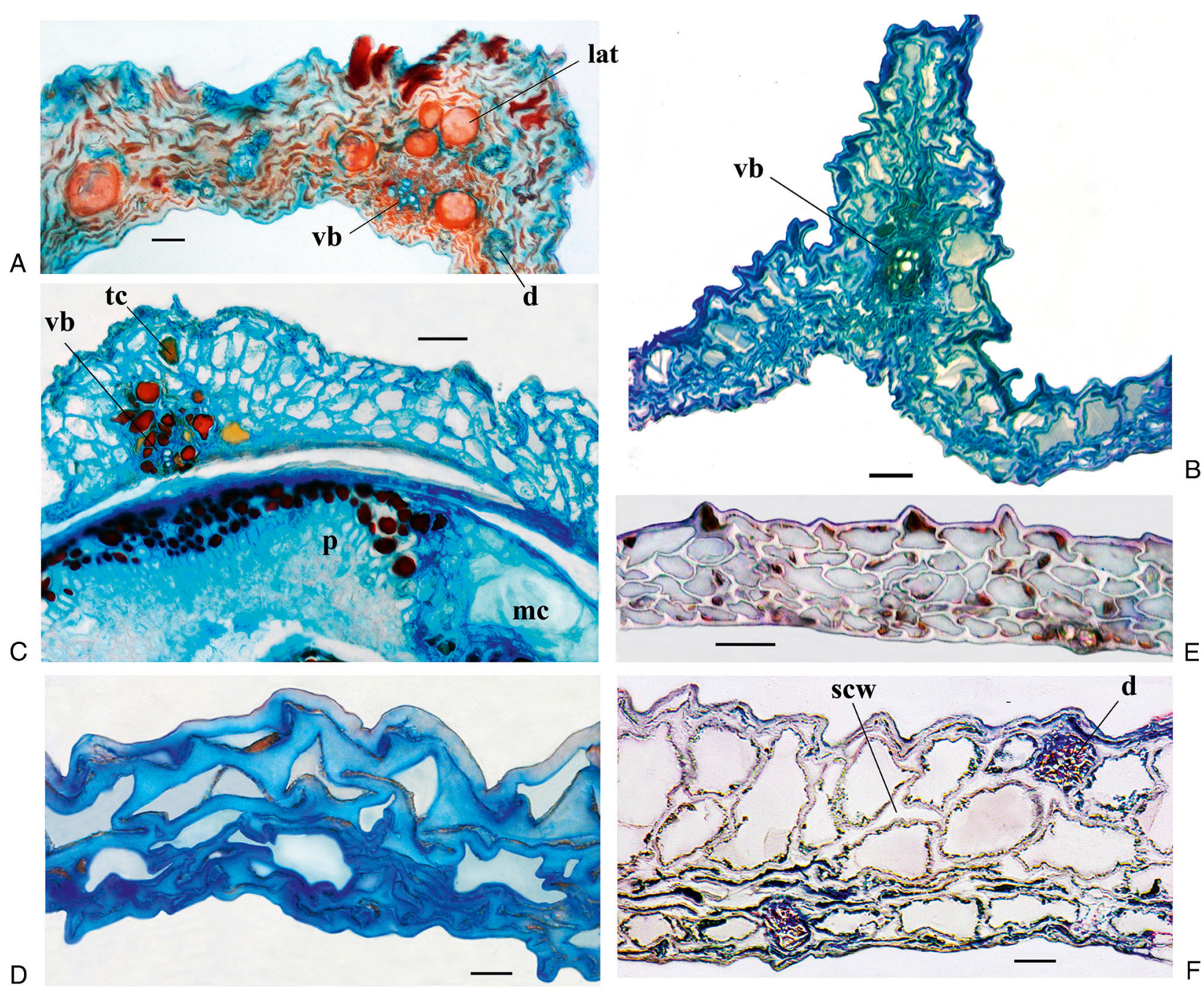

Fig. 5. Fruiting perianth in cross section; Poikilospermum subgenus Ligulistigma. A $P$. oblongifolium; B $P$. scortechinii, perianth rib; C P. tangaum, Clemens 29769; D P. tangaum, Coode 7622; E P. suaveolens; F P. naucleiflorum. d druse of calcium oxalate; ex exocarp; lat laticifer; mc mucilage cell; $p$ pericarp; scw silicified cell wall; tc tannin cell; vb vascular bundle. Scale bars: $A, E, G=20$ $\mu \mathrm{m}, \mathrm{B}, \mathrm{D}, \mathrm{F}, \mathrm{H}=10 \mu \mathrm{m}, \mathrm{C}=50 \mu \mathrm{m}$

(Poikilospermum inaequale, P. paxianum). Pericarp tubercle formation differs slightly in between species (Table 2; Fig. 4) except for the role of crystal cells, very large in the tubercles of $P$. acuminatum (Fig. 4D).

(i) Mesocarp: The outer zone is interrupted by pericarp tubercles; in Poikilospermum inaequale it is sometimes compressed together with the exocarp into a tannin-containing membrane covering a large area near to the fruit ribs (Fig. 4E). The middle zone is compressed and devoid of tannins or narrow tannincontaining; rarely with oval sclereids. The innermost crystalliferous zone is one-layered, containing druses of calcium oxalate (Fig. 7A, B).

(ii) Endocarp: Composed of lobed sclereids with lamellate walls, penetrated by numerous porous canals. Radial cell walls slightly protrude at the outer surface (Fig. 7H), making it rough. (iii) Pericarp ribs: Rounded or flat, almost equal in size to one another in the middle of fruits and unequal, sometimes slightly two-lobed (Poikilospermum inaequale, $P$. paxianum) at the base. The endocarp is represented by a multi-layered sclerenchyma strand. The number of vascular bundles in the fruit middle varies: two, in both pericarp ribs ( $P$. amboinense); one, only along r1 ( $P$. acuminatum); two, but well-developed only along r1 (other species).

(B) subgenus Ligulistigma

In the middle of the fruit the pericarp is five to six layered (Table 2; Figs 8, 9, 15A - F).

(i) Mesocarp: The outer zone is one-layered, more layered near fruit ribs, consisting of alternate mucilage and narrow non-mucilaginous cells with slightly thickened walls, sometimes strand-like. It is often interrupted in the middle of the 

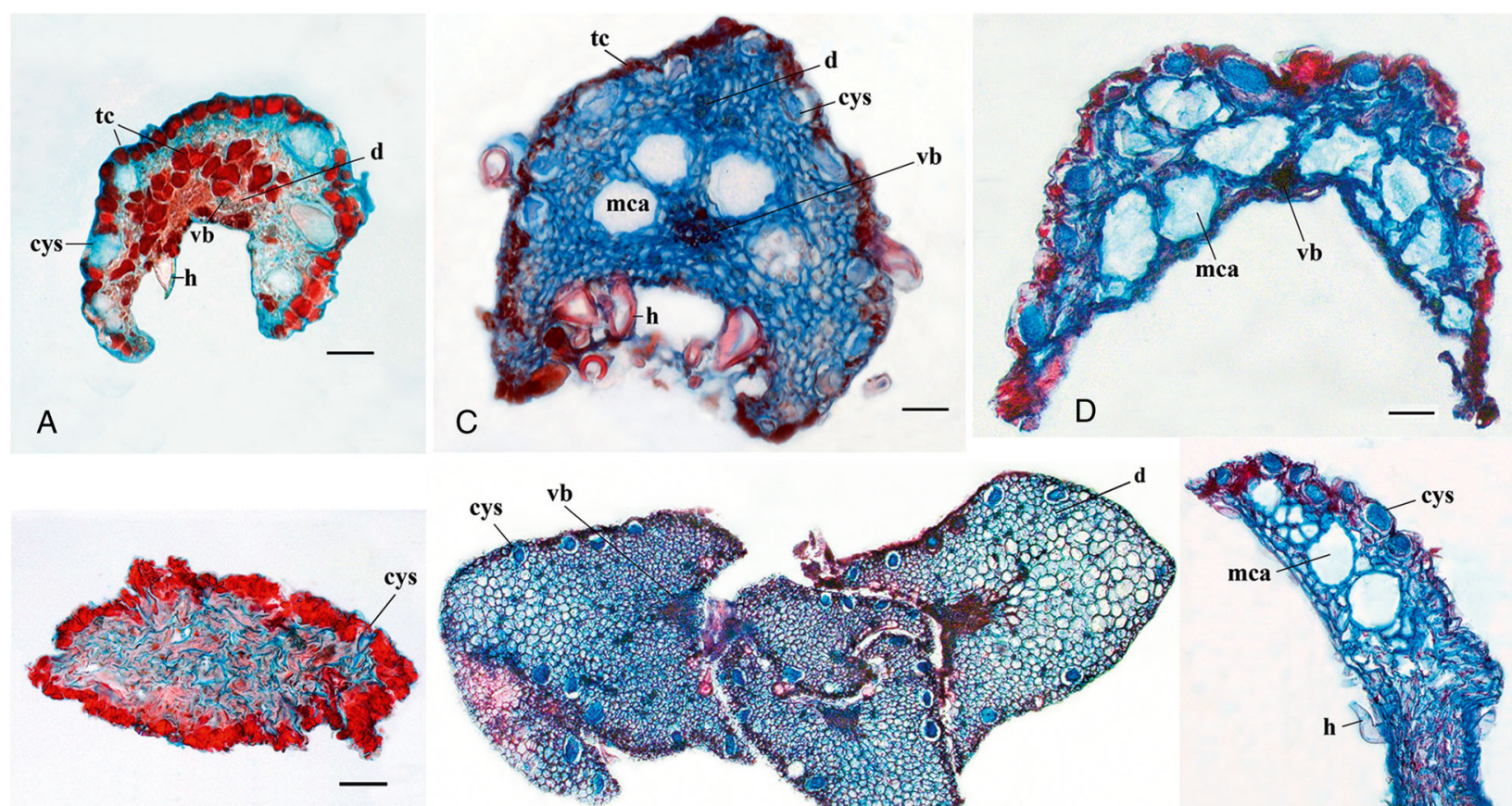

B
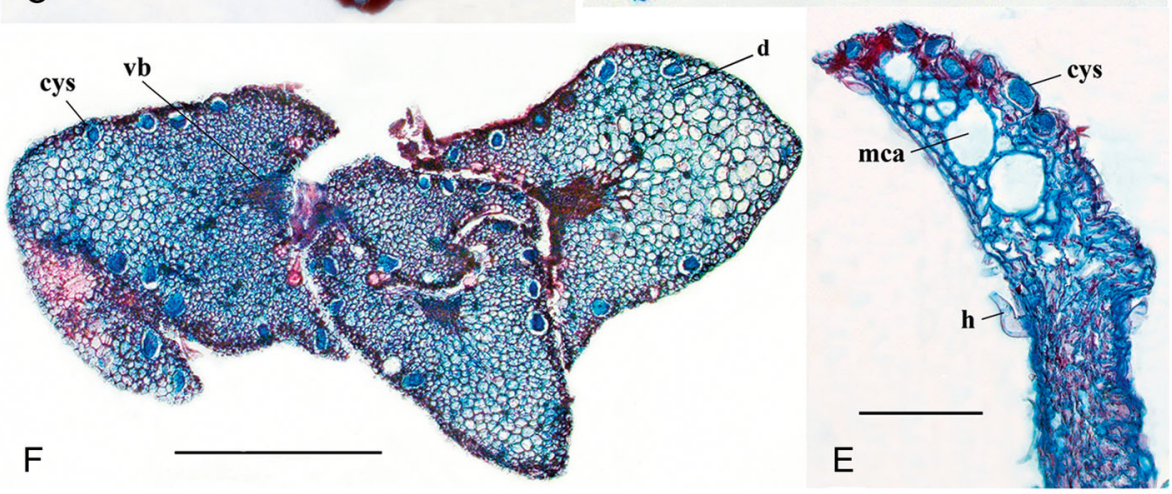

Fig. 6. Fruiting perianth lobe apices in cross section; Poikilospermum subgenus Ligulistigma. A P. scabrinervium, B $P$. scortechinii, $C$ P. cordifolium, D P. microstachys, E P. naucleiflorum, F P. peltatum. cys cystolith, d druse of calcium oxalate, h hair, mca mucilaginous cavity, tc tannin cell, vb vascular bundle. Scale bars: $A-D=50 \mu \mathrm{m}, E, F=500 \mu \mathrm{m}$

lateral fruit sides, where the inner mesocarp layers are adjacent to the exocarp. The middle zone is structurally diverse, four structural types and several variants may be distinguished.

(a) tannin-containing continuous: without mucilage cells; tannin cells (more or less thick-walled, parenchymatous or sclerenchymatous) are arranged in one to two layers; within tubercles they are radially elongated such that the surface of this tannin zone is alveolate; mucilage cells of the adjacent outer layer are located in the alveoles. Further variants are parenchymatous tannin-cells (Fig. 8A, B; 15A) and tannincontaining sclereids (Fig. 8E - G, 15B).

(b) tannin-containing interrupted (Fig. 9A, 15C): tannin cells interrupted by infrequent mucilage cells are arranged in an almost continuous zone in a layer mostly one, in places two to three cells wide.

(c) mucilaginous-parenchymatous (sparse tannincontaining) (Fig. 9B - D; 15D1, D2): alternate mucilage and parenchyma cells with irregularly thickened porous walls, sometimes tannin-containing (widely spaced). In Poikilospermum tangaum Clemens 29769 parenchyma cells are gathered in multicellular groups outnumbering the mucilaginous ones (Fig. 9C, D). Certain specimens of $P$. microstachys uniquely have tear-shaped tanniniferous content within cells in this layer (Fig. 15D1). (d) mucilaginous-sclerenchymatous (sparse tannincontaining) (Fig. 11D - G): tannin-containing or devoid of tannins sclereids arranged in one to two layers, are radially elongated to columnar; together with radially elongated endocarp sclereids and crystal cells they form more or less distinct alveoles in which mucilage cells are found.

The innermost zone (Table 2, Fig. 7C - G); in Poikilospermum scabrinervium alone, large fragments of the outer cell wall remain in the cells after their exfoliation (Fig. 7C) and crystal cells in surface view are longitudinally elongated. In $P$. naucleiflorum and $P$. suaveolens after exfoliation the adjacent fragments of the thickened cell walls of the superposed cell layer are present on the crystal layer surface (Fig. 7G). Druses are mostly globular, but star-shaped in P. lanceolatum (Fig. 7F). In P. naucleiflorum, $P$. cordifolium, $P$. scabrinervium, and P. tangaum Clemens 29769 (Fig. 9D) crystal cells are radially elongated, particularly in the tubercles and may contain one or two druses together with several small mineral inclusions.

(ii) Endocarp: Flat or slightly folded, usually thin, particularly in Poikilospermum microstachys and $P$. suaveolens, for which there is direct evidence of fruits squeezing from the perianth tube, although this characteristic is considered common to all subgenus 


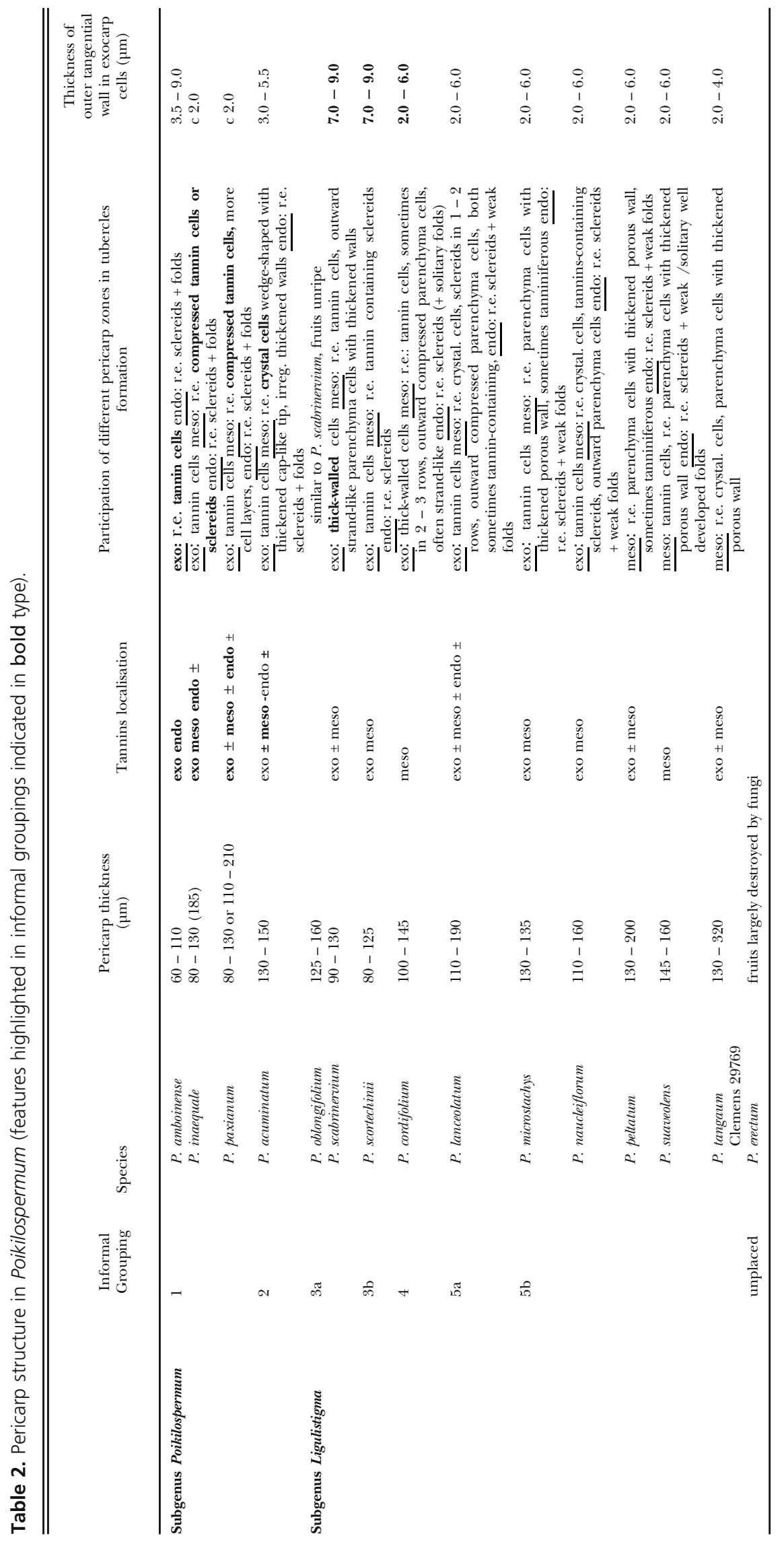




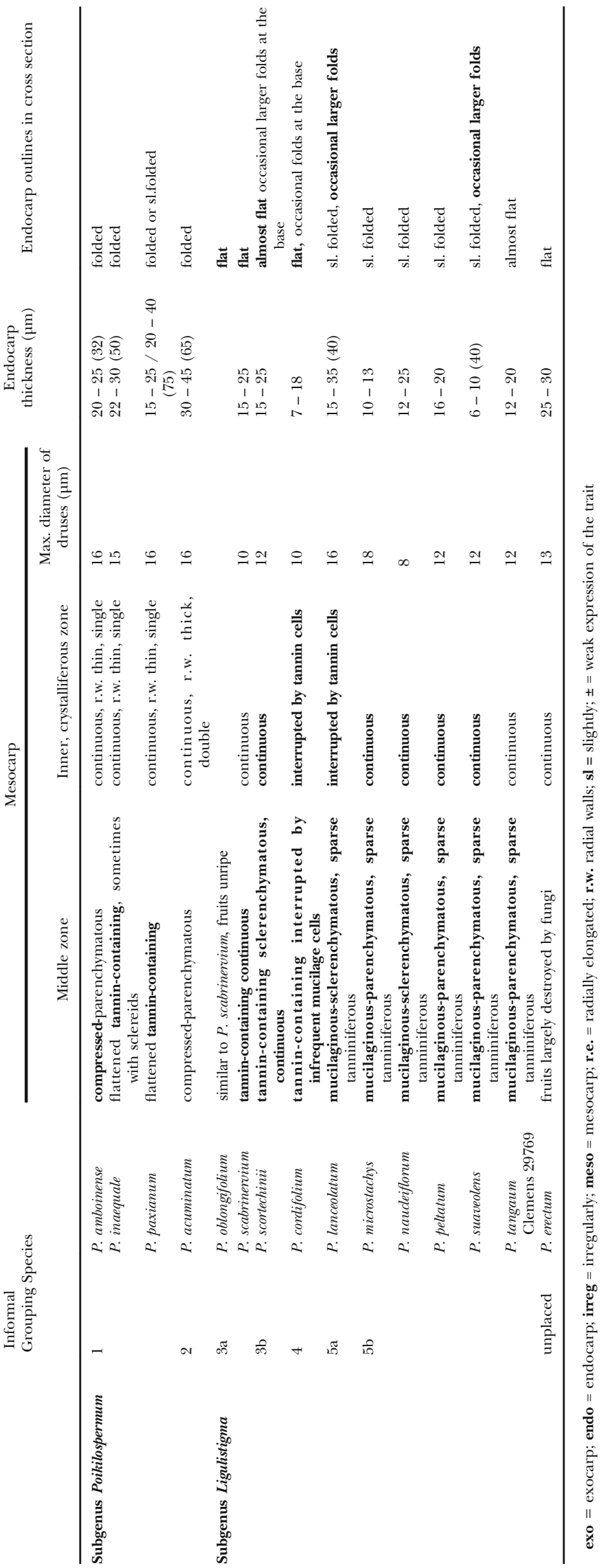

(c) The Author(s), 2020 

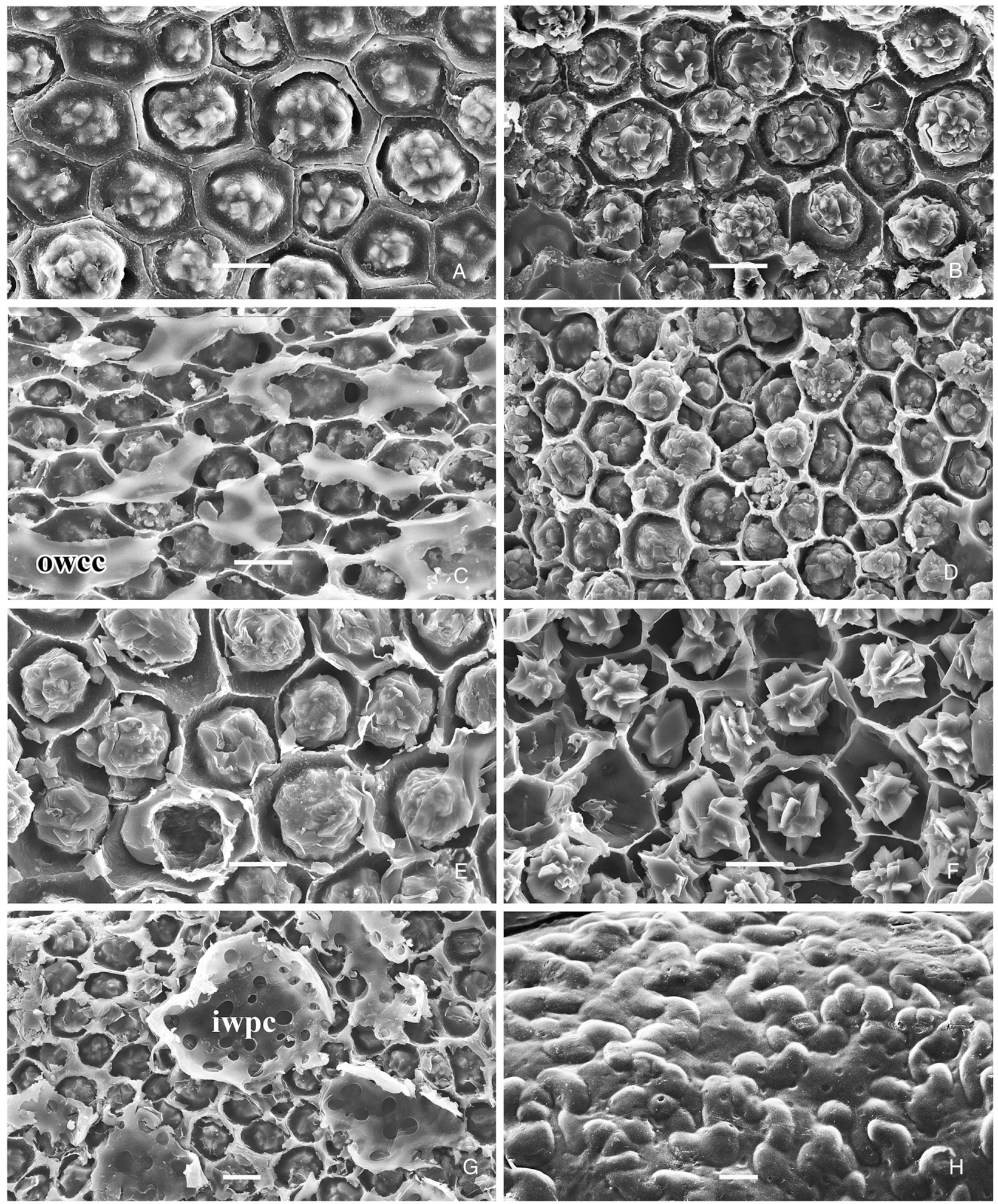

Fig. 7. Crystal layer and endocarp in surface view (SEM). A - G crystal layer: A $P$. acuminatum; B $P$. inaequale; C $P$. scabrinervium; D $P$. cordifolium; E $P$. microstachys; F $P$. lanceolatum; G $P$. suaveolens; $\mathrm{H}$ endocarp $P$. amboinense. iwpc separated inner tangential wall of outward parenchyma cell; owcc outer tangential wall of crystal-containing cell. Scalebars $=10 \mu \mathrm{m}$

Ligulistigma.

(iii) Pericarp ribs: The thickest ribs are found in the most asymmetrical fruits of Poikilospermum lanceolatum,
P. scabrinervium, P. tangaum Clemens 29769. Both fruit ribs may be similar or dissimilar in size and shape with varying r1:r2 ratios (Table 1, Figs 3D, 10A - E); r2 usually 

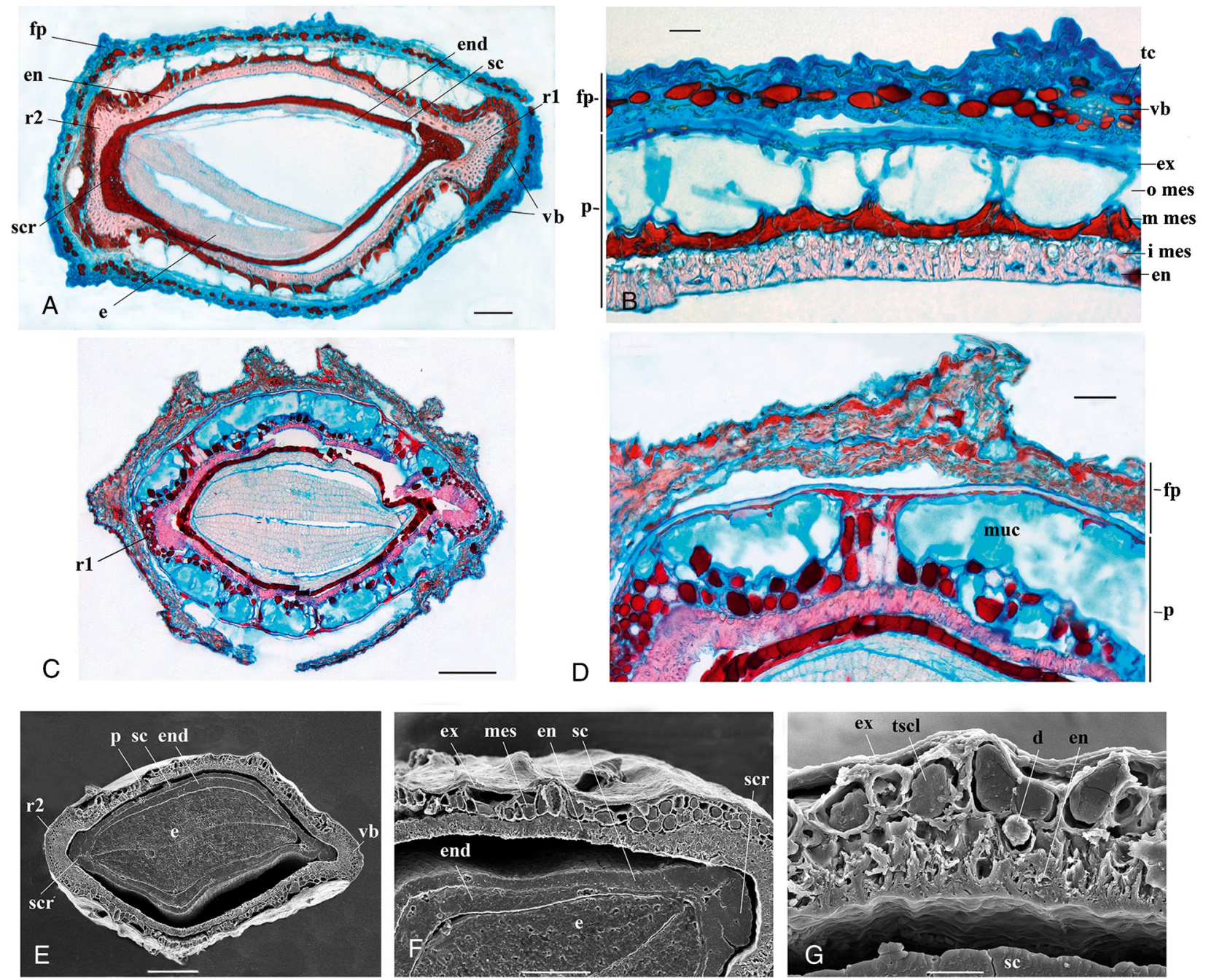

Fig. 8. Fruit and fruit wall in cross section; Poikilospermum subgenus Ligulistigma. A, B P. scabrinervium; C - G P. scortechinii (E - G SEM); A, C, E whole fruits (E without fruiting perianth); B, D, F, G portions of fruiting perianth and pericarp on lateral side of fruit; in $\mathrm{C}$ and $\mathrm{D}$ solid tanniniferous content has partially dropped out of mesocarp cells; stained with Safranin and alcian blue; $d$ druse of calcium oxalate; e embryo; en endocarp; end endosperm; ex exocarp; fp fruiting perianth; i mes inner mesocarp zone; mes mesocarp; muc mucilage; $m$ mes middle mesocarp zone; o mes outer mesocarp zone; $\mathrm{p}$ pericarp; $\mathrm{r} 1$ pericarp rib from fertile carpel's side; $r 2$ pericarp rib from suppressed carpel's side; sc seed coat; scr seed coat rib; tc tannin cell; vb vascular bundle; tscl tannin containing sclereid. Scalebars: $A, F=100 \mu \mathrm{m}, \mathrm{B}, \mathrm{G}=20 \mu \mathrm{m}, \mathrm{C}, \mathrm{E}=200 \mu \mathrm{m}, \mathrm{D}=50 \mu \mathrm{m}$

being larger. r1 usually differs from r2 in having a wider tannin zone (which in $\mathrm{r} 2$ is sometimes absent) and a smaller number of mucilage cells. The pericarp vascular bundle is often situated in a groove.

The pericarp ribs have an unusual feature: at the fruit apex deep, slit-like longitudinal grooves occur on their inner sides, into which narrow seed coat projections ('wings') enter. The ribs are easily split where these grooves are present which occurs mainly at the level of the upper portion of the radicle, but in Poikilospermum microstachys at the level of the cotyledons (Fig. 10C). In P. oblongifolium and $P$. scabrinervium the groove is absent in $\mathrm{r}$, , present in r1; the latter remains thick, thus does not split at the fruit apex.

\section{Seed Coat Structure}

The seed coat is three to four-layered with discernible cellular structure in tannin-containing exo- and endotesta, and sometimes mesotesta (a derivative of the outer subepidermis of the outer integument); the endotegmen is thin, structureless and is separated from the remnants of the nucellus by a thin cuticle (Figs 3E, 11A-H). The seed coat surface is perforated or without holes (Fig. 13).

\section{(A) Subgenus Poikilospermum}

The seed coat is thinner than subgenus Ligulistigma (particularly in Poikilospermum paxianum - Fig. 11B), composed of two or three compressed tannincontaining cell layers; the endotesta is especially weakly 
A
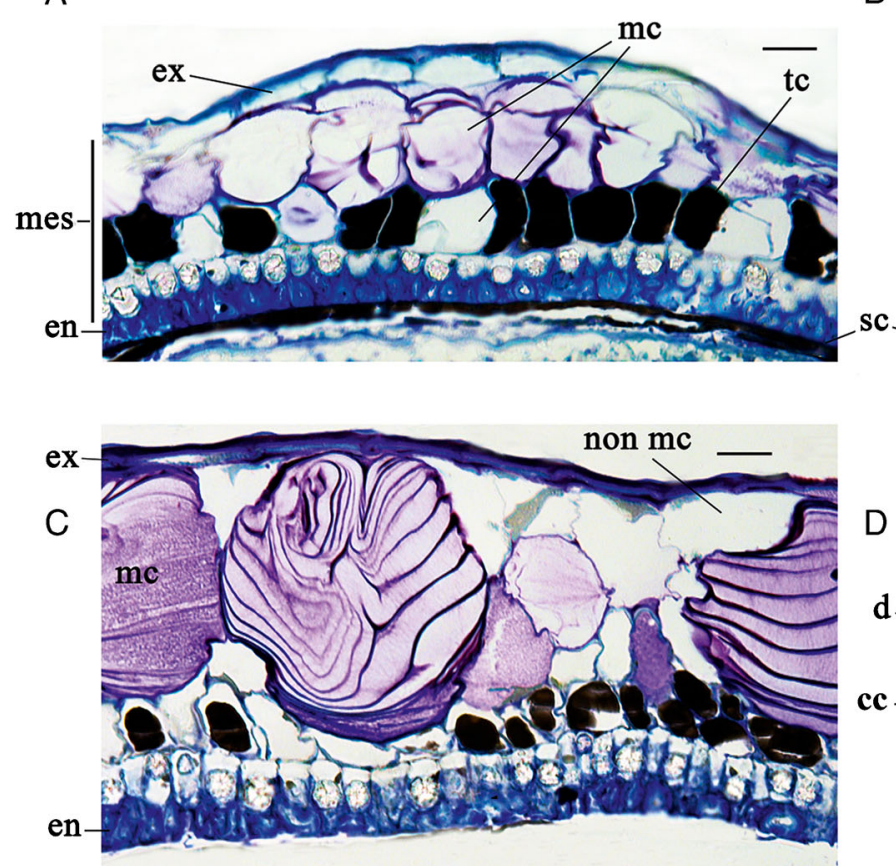

B
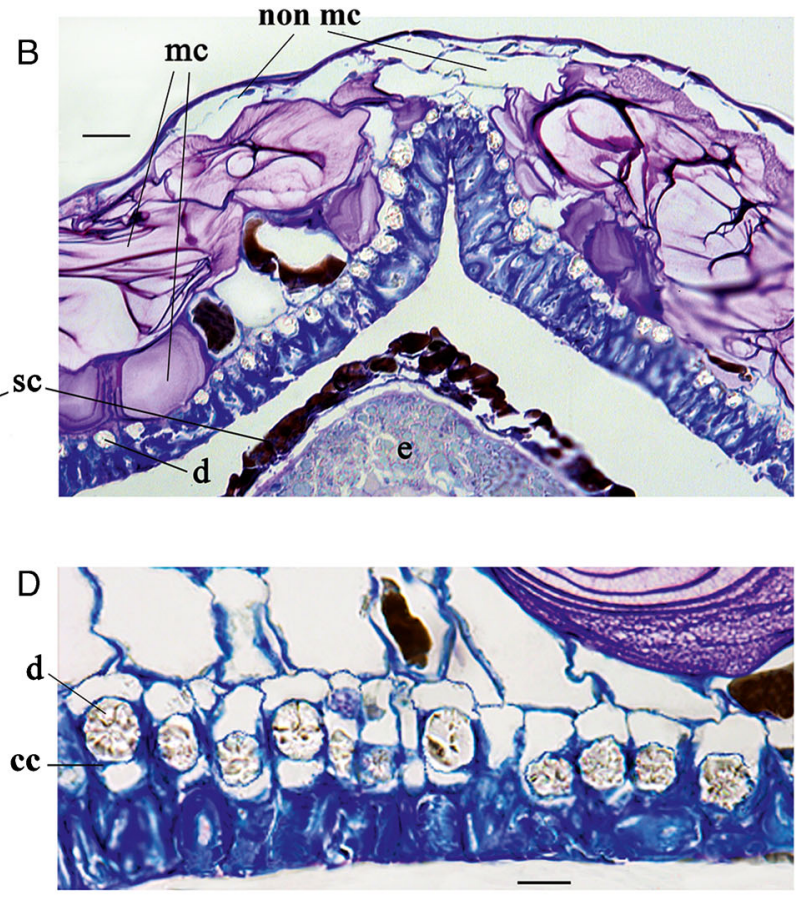

Fig. 9. Fragments of pericarp in cross section; Poikilospermum subgenus Ligulistigma. A $P$. cordifolium; B P. suaveolens; C, D P. tangaum, Clemens 29769; A - D portions of pericarp on lateral side of fruit, stained with toluidin blue; cc crystal cell, d druse of calcium oxalate; e embryo; en endocarp; ex exocarp; mc mucilage cell; mes mesocarp; non mc cell without mucilage; sc seed coat; tc tannin cell. Scalebars: $A-C=20 \mu \mathrm{m}, \mathrm{D}=10 \mu \mathrm{m}$

developed (Table 3; Fig. 11A - C). The cells are less compressed in the endocarp folds, seed ribs, and beneath the exotesta holes than in the other seed parts occasional mesotesta cells occur (Fig. 11C).

\section{(B) Subgenus Ligulistigma}

The seed coat structure is more diverse than in subgenus Poikilospermum (Table 3; Fig. 11D - H); exotesta and one to three inner cell layers vary in amount of compression. The seed coat is usually thicker in the endocarp folds and seed ribs where it forms testa ribs and in certain species it narrows into wing-shaped edges in the upper seed part (Fig. 10C). The ribs of the comparatively thick seed coats are large and loose, sometimes folded and often of varying shape within the same seed (Figs 8A, E; 10A, B).

Unlike in the thin seed coat (Fig. 11D) where all the cell layers are compressed, in the thicker seed coats (Fig. 8A, C $-\mathrm{F}$; 11E $-\mathrm{H}$ ) they are less flattened and contain a larger amount of tannins; both exo-and mesotesta are better developed, especially in Poikilospermum scabrinervium, where the mesotesta forms an almost continuous layer closer to the seed ribs. In most species it is distinguishable in places. To clarify seed coat histogenetic zonality further developmental research is required. i) Endotesta: Endotesta cells vary greatly in shape within the same seed in all Ligulistigma species (Table 3; Fig. 12B - E). They are mostly transversely elongated, and loosely arranged in one to two layers. Their loosest arrangement is in Poikilospermum peltatum and P. suaveolens (Fig. 12C, D) where the dominance of short cells (rounded and oval) combines with the most marked variation in their shape and orientation. By contrast in P. microstachys (Fig. 12E) and $P$. naucleiflorum, long transversely elongated endotesta cells prevail.

ii) Exotesta structure and surface: The seed coat surface is uniformly perforated in subgenus Poikilospermum (Fig. 13A). In Ligulistigma species (Fig. $13 \mathrm{~B}-\mathrm{J}$ ) it is either not perforated or has small, slit-like or round holes (intercellular spaces), gathered in chains along the radial cell walls (Fig. 13B - D). The primary sculpture is more diverse than in subgenus Poikilospermum (Table 3); sometimes on the seed surface there are impressions of closely adjacent endocarp sclereids (Fig. 13B). Exotesta cells are longitudinally elongated; their boundaries not always visible from above. Where the seed coat is thin the exotesta cells are long and linear, where comparatively thick - either linear (Fig. 13C) or vary within a seed in size and shape (Fig. 13E - J). 

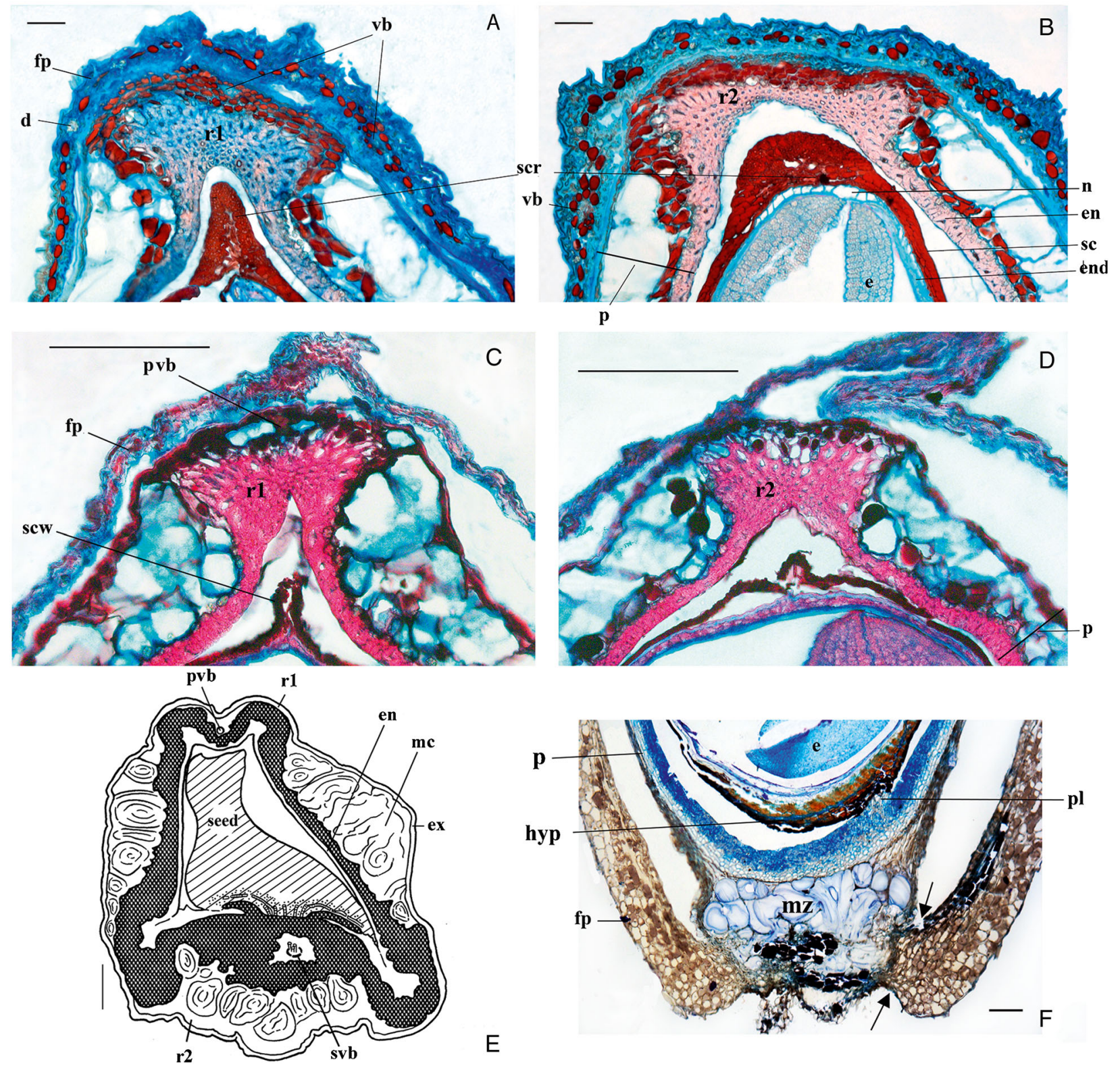

Fig. 10. Pericarp ribs and fruit base in cross $(A-E)$ and longitudinal $(F)$ sections. $A, B$ unequal pericarp ribs in Poikilospermum scabrinervium, Wong WKM1285: A pericarp rib from fertile carpel's side; B pericarp rib from suppressed carpel's side; C, D almost equal pericarp ribs in P. microstachys, Corner 5369: C pericarp rib from fertile carpel's side; D pericarp rib from suppressed carpel's side; $\mathrm{E}$ pronounced difference in pericarp ribs in $P$. oblongifolium (fruit unripe); $\mathrm{F}$ fruit base in $P$. naucleiflorum, arrows $=$ place of pericarp and perianth tube detachment, A - D fruit middle part, E, F fruit base. d druse of calcium oxalate; e embryo; en endocarp; end endosperm; ex exocarp; fp fruiting perianth; hyp hypostase; mc mucilage cell; mz mucilaginous zone of stipe; $n$ nucellus (remnants); $p$ pericarp; pl placenta; pvb pericarp vascular bundle; $r 1$ pericarp rib from fertile carpel's side; $r 2$ pericarp rib from suppressed carpel's side; sc seed coat; scr seed coat rib; scw seed coat wing; svb seed vascular bundle; vb vascular bundle. Scalebars: $A, B=50 \mu \mathrm{m}, C, D=200 \mu \mathrm{m}, E, F=100 \mu \mathrm{m}$

7. Informal grouping of species according to fruit structure

(A) Subgenus Poikilospermum

Group 1. Poikilospermum amboinense (Figs 1A; 2P; 3A; 4A, B; 7H; 11A; 13A), P. inaequale (Figs 1D; 2A, B; 4E, F; 7B), P. paxianum (Figs 1E, F; 2C; 3B; 4G -J; 11B, C).
Diagnostic features:

(i) Fruiting perianth: thick, with large amounts of tannins in the two outer layers or thin and ribbed. Tannins (not numerous) are localised mostly in the mesophyll cells, in Poikilospermum inaequale sometimes in both epidermal layers, as in P. acuminatum. 

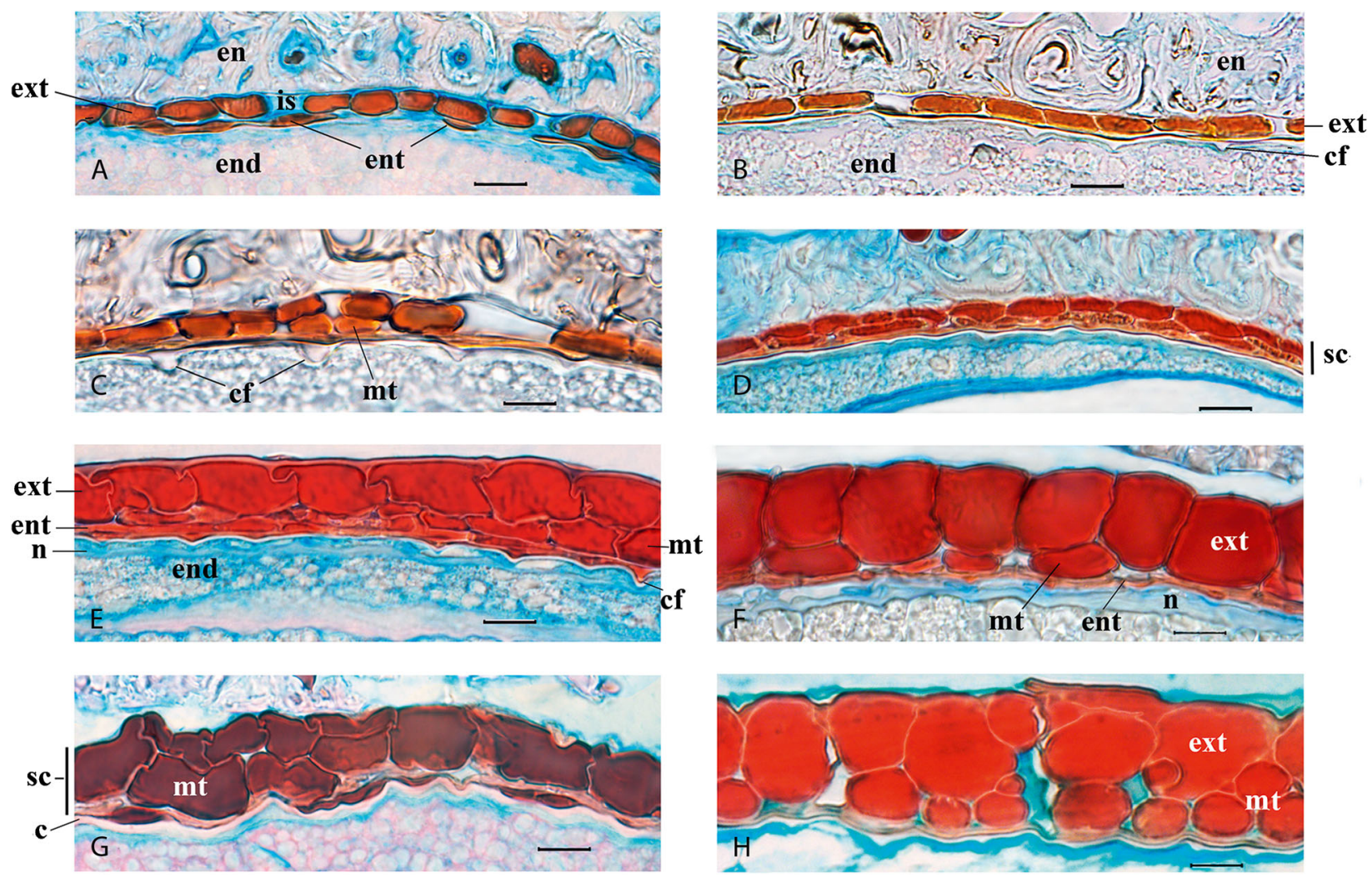

Fig. 11. Seed coat in cross section. A - H portions of cross section on lateral side of seed. A Poikilospermum amboinense; B, C P. paxianum (different portions); D P. cordifolium; E P. scabrinervium; F P. scortechinii; G P. lanceolatum; H P. tangaum, Clemens 29769; c cuticle; cf cuticular fold; en endocarp; end endosperm; ent endotesta; ext exotesta; is intercellular space; mt mesotesta; $\mathrm{n}$ nucellus; sc seed coat. Scalebars $=10 \mu \mathrm{m}$

(ii) Pericarp: tannin cells are absent (Poikilospermum amboinense) or present (P. inaequale, $P$. paxianum) in the mesocarp, where they form a compressed middle zone whilst certain, radially-elongated, narrow tannin cells of this layer are involved in tubercle formation. In $P$. amboinense and sometimes in $P$. inaequale alternate cells of exo- and mesocarp form a tanniniferous and mucilaginous exo-mesocarp (Fig. 4A, B); pericarp tubercles are formed in these species with the participation of radially-elongated tannin cells of the exocarp and in P. inaequale sometimes mesocarp sclereids also.

Group 2. Poikilospermum acuminatum (Figs 1B, C; 4C, D; 7A; 12A).

Diagnostic features:

(i) Fruiting perianth: thick, with large amounts of tannins in both epidermal layers.

(ii) Pericarp: tannin cells are absent in the mesocarp. Uniquely in the genus pericarp tubercles are formed with the participation of large, radially-elongated crystal cells.

(B) Subgenus Ligulistigma

Group 3. Poikilospermum oblongifolium (Figs 5A, 10E), P. scabrinervium (Figs 1H, J; 2D - F, Q; 6A; 7C; 8A, B;
10A, B; 11E; 12B; 13E - G; 15A, G), P. scortechinii (Figs 2G; 5B; 6B; 8C - G; 11F; 13H, J; 15B).

Diagnostic features:

(i) Fruiting perianth: rather dense and coriaceous with lobe apices not swollen and devoid of mucilage cavities. (ii) Pericarp: large amount of tannins present, exocarp cells with considerably thickened outer tangential walls, mucilage localisation only in the outer mesocarp zone, continuous tannin-containing middle mesocarp zone, flat endocarp.

(iii) Seed coat: comparatively thicker with better developed mesotesta than in other Ligulistigma species; large marginal ribs of different shapes within a seed; reticulate primary sculpture; uncompressed or slightly compressed tannin-filled exotesta cells which in surface view vary from short irregular-polygonal to linear.

Group 3a. Poikilospermum oblongifolium, P. scabrinervium Fruits are comparatively small, often inequilateral, with well-developed ribs which are isolated by furrows from the raised, lateral fruit sides; the two pericarp ribs differ sharply in size and shape, especially in the lower part of the fruit where the larger rib (r2) is two-lobed. This heterocarpy along with the presence of both more or less symmetrical and asymmetrical fruits within the same collection is more 


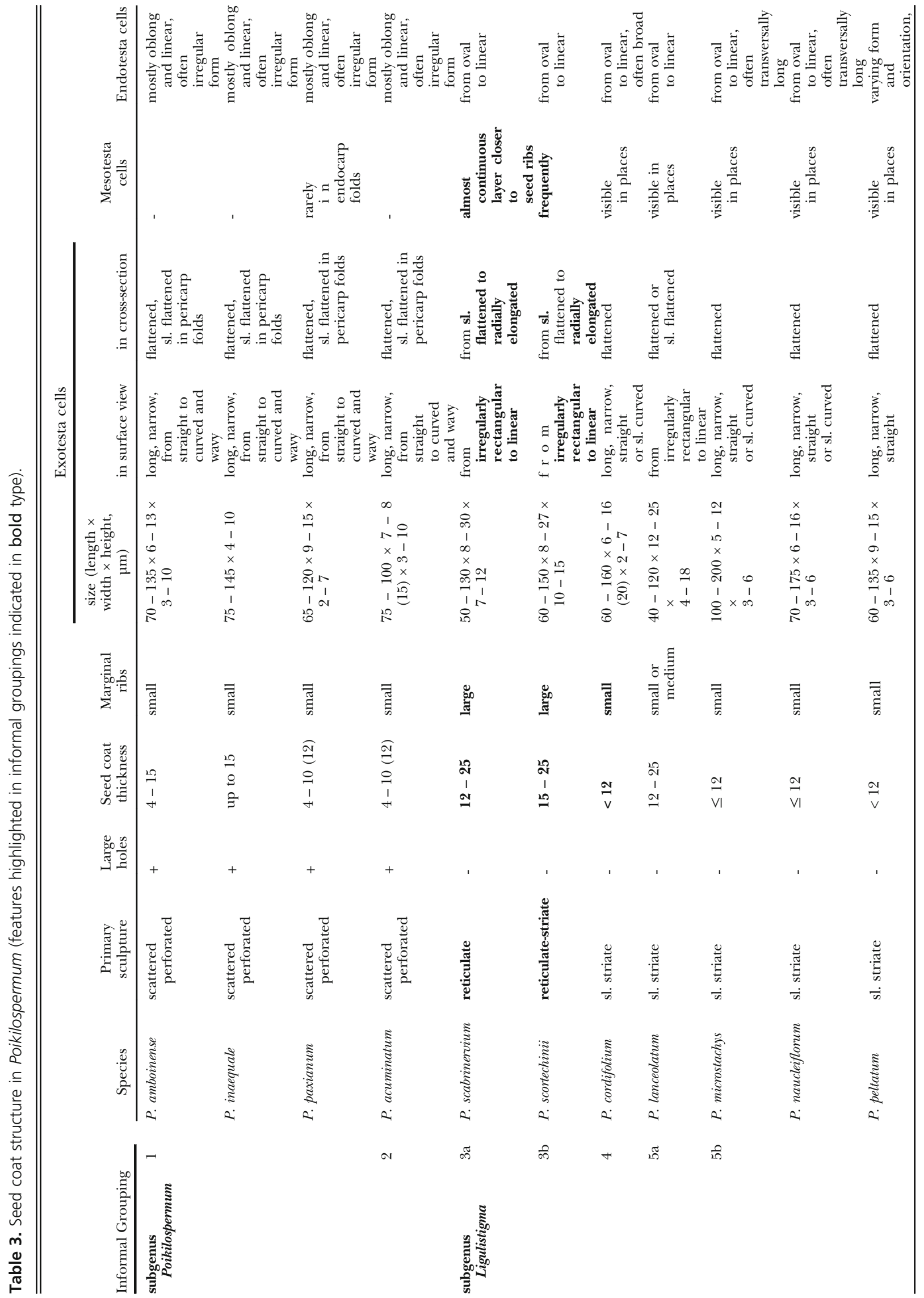




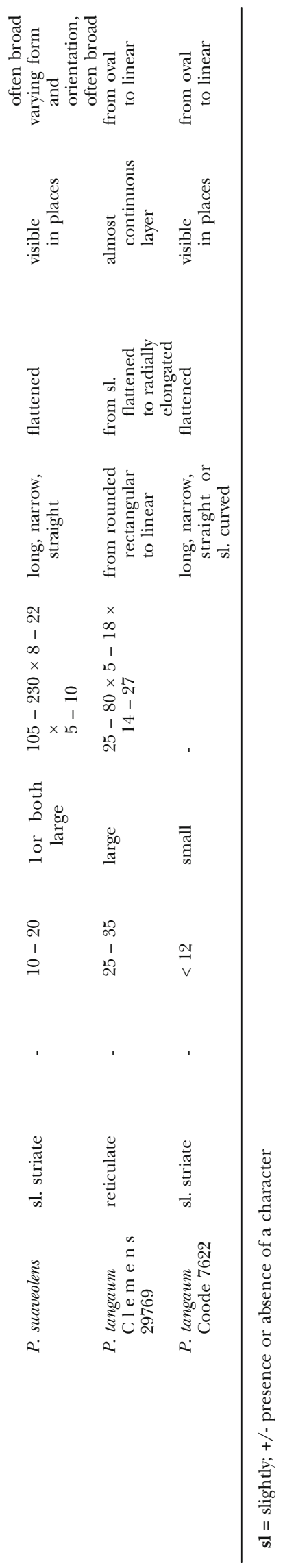

strongly expressed than in the other species and involves an embryo which in the asymmetrical fruits is sometimes slightly curved. The fruiting perianth has weakly-thickened ribs and lobe apices and uncompressed tannin cells in the mesophyll, arranged in an almost complete unicellular layer (Poikilospermum scabrinervium) or around vascular bundles ( $P$. oblongifolium); lobe apices are dense with large cystoliths, round or from round to linear ( $P$. scabrinervium) or oval ( $P$. oblongifolium). In P. scabrinervium exocarp cells in prominent regions are thick-walled with both outer and inner tangential walls thick (Fig. 15A). The continuous, tannin-containing middle mesocarp zone consists of tannin-filled parenchyma cells.

\section{Group 3b. Poikilospermum scortechinii}

Fruits small, often seem equilateral, with weaklydeveloped ribs; the surface is distinctly verrucose with submarginal tubercles; the fruiting perianth has folds and ribs along and between the veins, formed by radially-elongated, subepidermal cells filled by latex; the lobe apex is sclerified with scarce and virtually indiscernible cystoliths. The continuous tannin-containing middle mesocarp zone consists of tannin-containing sclereids.

Group 4. Poikilospermum cordifolium (Figs 6C, 7D, 9A, 11D, 15C)

Diagnostic features:

This species shares some carpological characters with groups 3 and 5. Fruits are mostly equilateral, with well-developed ribs that are isolated by furrows from raised, lateral fruit sides; r2 forms a keel; the fruiting perianth is thin, lobe apices are considerably thickened with mucilage cavities of medium size; cystoliths are rather small; in the exocarp, outer tangential cell walls are thin; the tannincontaining middle mesocarp zone is interrupted rarely by mucilage cells and the crystalliferous layer is interrupted; the seed coat is thin, without large marginal ribs.

Group 5. Poikilospermum lanceolatum (Figs 1G, 2H, 7F, 11G, 15E), P. microstachys (Figs 1R, S; 2K - M, S; 6D; 7E; 10C, D; 12E; 13B; 15D1, D2, H), P. naucleiflorum (Figs $1 \mathrm{M}, \mathrm{N} ; 2 \mathrm{~N} ; 5 \mathrm{~F} ; 6 \mathrm{E} ; 10 \mathrm{~F} ; 13 \mathrm{D} ; 15 \mathrm{~F}$ ), P. peltatum (Figs 1P, Q; 2R; 3C, D; 6F; 12C), P. suaveolens (Figs 1L; 5E; 7G; 9B; 12D; 13C), P. tangaum (Figs 1K; 2J; 5C, D; 9C, D; 11H).

Diagnostic features:

(i) Fruiting perianth: lobe apices thicker than in group 3, with large, numerous, mucilaginous cavities or consisting of small-cellular parenchyma.

(ii) Pericarp: a small amount of tannins; comparatively thin outer tangential wall of exocarp cells; mucilage localisation in the outer and middle mesocarp zones 

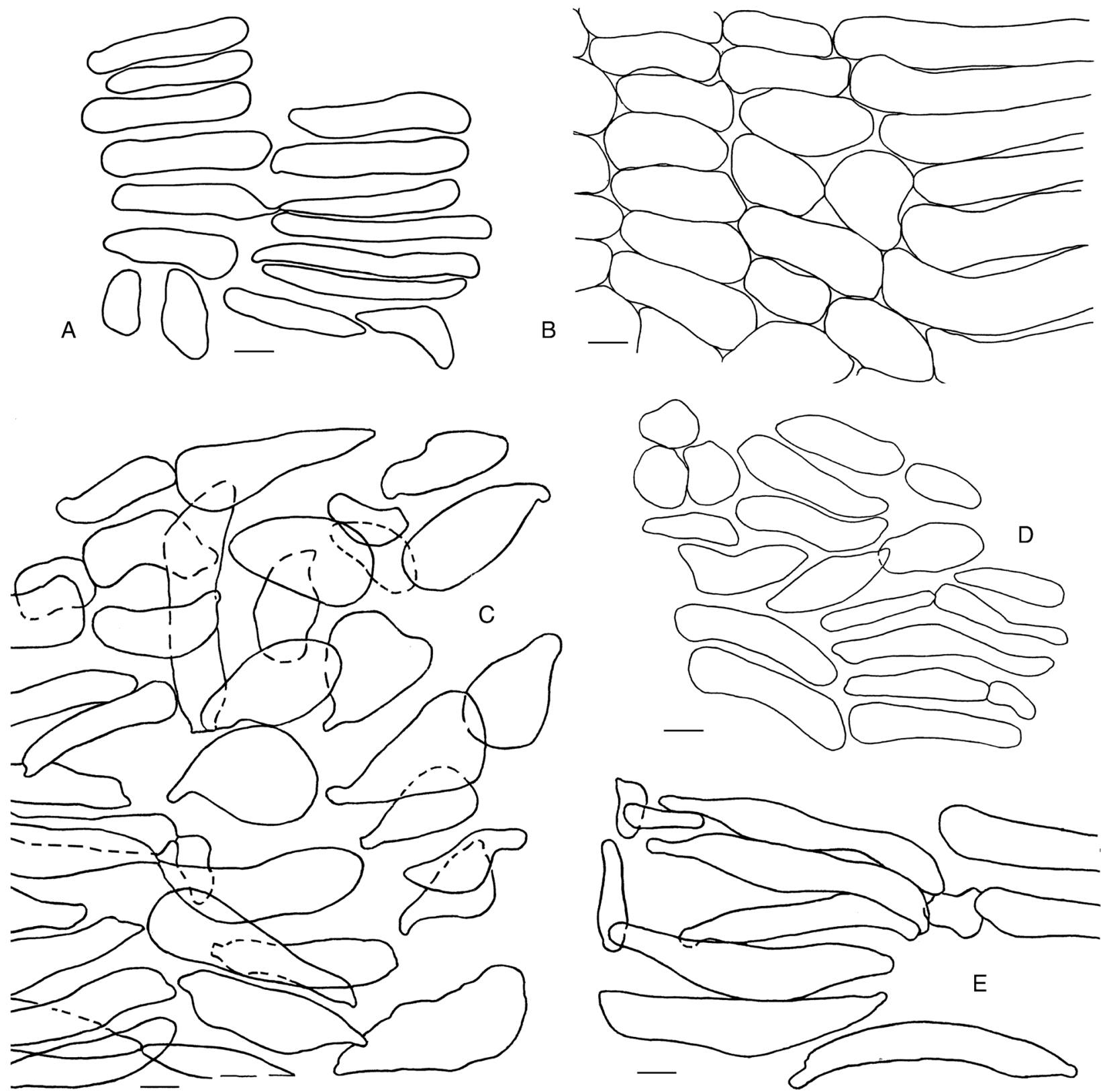

Fig. 12. Seed coat inner layers in surface view. A Poikilospermum acuminatum; B $P$. scabrinervium; C $P$. peltatum; D $P$. suaveolens; E P. microstachys, Corner 5369. A, C - E endotesta, B mesotesta. The line at the left shows fruit's longitudinal axis. Scalebars $=10$ $\mu \mathrm{m}$

which are sparse-tanniniferous, mucilaginousparenchymatous or mucilaginous-sclerenchymatous; slightly folded endocarp, sometimes with larger, occasional folds.

(iii) Seed coat: mostly only slightly thickened; absence of thick ribs; usually poorly developed mesotesta.

\section{Group 5a. Poikilospermum lanceolatum:}

Fruits are often inequilateral with a long stipe and a distinctly verrucose, spotty surface (tubercles stained brown); fruiting perianth is inversely pyriform, the middle mesocarp zone is an alveolate-mucilaginous- sclerenchymatous, interrupted crystalliferous layer with star-shaped druses; large occasional folds of the endocarp.

Group 5b. Poikilospermum microstachys, P. naucleiflorum, $P$. peltatum, $P$. suaveolens, $P$. tangaum Coode 7622:

Fruits are often almost equilateral and narrow, with a short stipe; in some species fruits apically dehisce and squeeze out of the perianth tube; the surface is indistinctly small-tuberculate or longitudinally rugose; fruiting perianth is not inversely pyriform; the middle mesocarp zone is mucilaginous-parenchymatous 

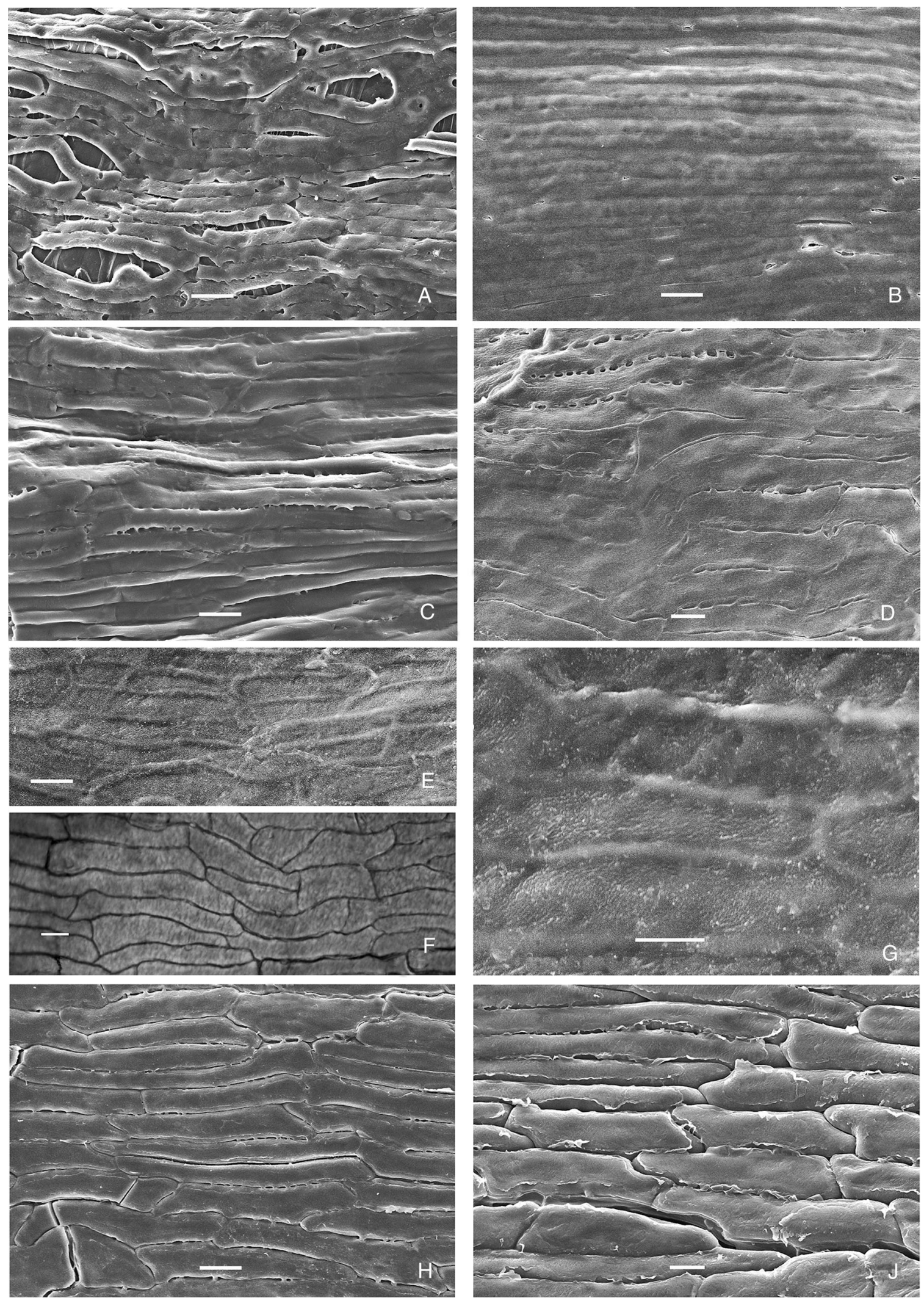

Fig. 13. Seed coat surface. A Poikilospermum amboinense; B P. microstachys, Corner 5369; C P. suaveolens; D P. naucleiflorum; E G P. scabrinervium, Wong WKM1285, different fragments and magnifications; H, J P. scortechinii, different fragments and magnifications. Scalebars: A - C, E, F, H $=20 \mu \mathrm{m}, \mathrm{D}, \mathrm{G}, \mathrm{J}=10 \mu \mathrm{m}$ 
(sparse tannin-containing) or mucilaginoussclerenchymatous whilst also alveolate (Poikilospermum naucleiflorum); continuous crystalliferous layer with globular druses.

The peculiar features of Poikilospermum suaveolens are large occasional folds of the endocarp and extreme reduction of the suppressed carpel.

Poikilospermum tangaum shows variation both in fruit and seed characters and requires further investigation. In Clemens 29764 fruits are pyriform, within the pericarp there is a predominance of parenchyma cells in the middle mesocarp zone and radially-elongated crystal cells containing several mineral inclusions; the seed coat is comparatively thick, with well-developed, tanniniferous testa; mucilaginous cavities are absent in the perianth lobe apex. The collection Coode 7622 has different states of these characters; the only common traits are the shape of the pericarp ribs and the general pericarp structure.

The fruit structure also varies considerably in Poikilospermum microstachys. The two collections studied differ in fruit shape (oblong / shorter narrow elliptic and more inequilateral); exocarp surface (tuberculate / indistinctly longitudinally, rugose-wrinkled); the shape of the solid, tanniniferous inclusions in the mesocarp cells (tear-drop only in the one collection); the fruiting perianth structure.

\section{Discussion}

1. Correlation of informal groupings based on fruit structure with gross morphology and geographical distribution and some evolutionary observations

(A) Subgenus Poikilospermum

Group 1. Poikilospermum amboinense, P. inaequale, $P$. paxianum

Several unique features (the particular structure of fruiting perianth, sometimes underdeveloped; simplified mesocarp structure) may indicate a somewhat isolated position of Poikilospermum amboinense within the group, perhaps early diverged from the common root of the subgenus. This derived state of the pericarp structure shows strong correlation with great morphological variability (in e.g. fruiting perianth, lamina and peduncular bract size) and the widest distribution in Eastern Malesia, being the only species in the subgenus to extend westwards into the Moluccas.

Group 2. Poikilospermum acuminatum

The mechanism of tubercle formation in Poikilospermum acuminatum is unique within the whole genus Poikilospermum. This shows a strong correlation with gross morphology; the inflorescence structure in this species is also unique within the genus: flowers are borne on minute, peduncu- lar receptacles rather than freely (subgenus Poikilospermum) or on fleshy capitula (subgenus Ligulistigma). It therefore occupies a somewhat intermediate position between the subgenera but is included in subgenus Poikilospermum by virtue of certain floral characters and the presence of fruit not wholly enclosed by a persistent perianth (Chew 1963). The lack of solitary terminal flowers in its female inflorescences separates it from the rest of the subgenus and geographically it can be regarded as isolated, being endemic to the Philippine islands.

\section{(B) Subgenus Ligulistigma}

Group 3. Poikilospermum oblongifolium, P. scabrinervium, P. scortechinii

Again, this grouping shows strong correlation with gross morphology in that these three species all exhibit repeated dichotomous branching of the male inflorescences, numerous floral capitula, crescentic stipules and the absence of a splitting periderm in the twigs. They are also all present in Borneo, considered by Chew (1963) to be one of the centres of diversity for this subgenus.

Group 3a. Poikilospermum oblongifolium, P. scabrinervium The distribution of the group is restricted to the islands of Borneo and the Philippines, Poikilospermum oblongifolium being found on both, $P$. scabrinervium being endemic to Borneo.

\section{Group 3b. Poikilospermum scortechinii}

The derived states of the fruit characters (hard middle mesocarp and fruiting perianth, the absence of a twolobed fruit rib) correlate with the broader distribution of this species within Western Malesia (Borneo, Sumatra, Malay Peninsula). It can also be distinguished morphologically from the rest of group 3 by its very short petioles, caducous stipules (leaving prominent stipule scars present on the twigs) and the occasional presence of arched (rather than straight) venation.

\section{Group 4. Poikilospermum cordifolium}

Morphologically Poikilospermum cordifolium stands out from other subgenus Ligulistigma species on the basis of size, having the largest lamina in the subgenus. It also displays stout twigs and petioles, large, crescentic, persistent stipules and larger than average female inflorescences. The distribution of the species is similar to $P$. scortechinii: throughout Western Malesia (Borneo, Sumatra, Malay Peninsula) but also extends west into Thailand.

Group 5. Poikilospermum lanceolatum, P. microstachys, $P$. naucleiflorum, $P$. peltatum, $P$. suaveolens, $P$. tangaum There is strong correlation with distribution as this group of species accounts for all the currently known 
records for Poikilospermum within Continental Asia (India, Myanmar and China) and Indochina (Vietnam, Laos and Cambodia). Variation in certain features of pericarp structure within species of group 5 show correlation with both distribution and ecology. Subgenus Ligulistigma radiates from two centres of distribution, Malesia and Continental Asia (Chew 1963). Poikilospermum lanceolatum and P. naucleiflorum (continental Asia, Thailand and Indochina) inhabit monsoon forests and have more sclerified pericarp than the other species of the subgenus as a whole (Western Malesia) which inhabit rain forests. In these two species the endocarp is thick (up to 25 or $35 \mu \mathrm{m}$ ) and the middle mesocarp zone is mucilaginous-sclerenchymatous instead of mucilaginous-parenchymatous.

\section{Group 5a. Poikilospermum lanceolatum}

Anatomically distinct within group 5, this species can also be separated morphologically from the others in the group by the presence of long, straight stipules. It differs from all others in the group except Poikilospermum microstachys in relatively few, and small sized, female inflorescences and from $P$. microstachys in its inflorescences being always branched more than once.

Group 5b. Poikilospermum microstachys, P. naucleiflorum, $P$. peltatum, $P$. suaveolens, $P$. tangaum Coode 7622

Poikilospermum suaveolens, which occupies an intermediate position in fruit structure between groups (4) and (5b) and also shows extreme reduction of the suppressed carpel (which as discussed further below implies that it may be one of the younger species of the genus), is the most widely distributed species in subgenus Ligulistigma; it ranges from Continental Asia, through Thailand, Indochina and most of Malesia as far east as the Moluccas. This correlation is similar to the situation in $P$. amboinense (subgenus Poikilospermum) where a derived state of the pericarp shows correlation with the widest distribution in East Malesia.

\section{Possible evolutionary trends in fruit morphology}

The results obtained show that heterobathmy appears to be exhibited by the genus Poikilospermum, at both subgeneric and species level, with respect to different degrees of specialisation of flower, fruit and seed organisation. Although the presence of more primitive characters, such as the fruiting perianth not enclosing the fruit and the absence of specialised capitate inflorescences with swollen receptacles, is characteristic of subgenus Poikilospermum, this study shows that subgenus Ligulistigma possesses a different set of primitive characters such as the remnant of the second carpel and ovary loculus as well as a primitive, less simplified seed coat, alongside its more derived character states.
Based on this study some possible evolutionary trends may be traced in fruit, seed, and fruiting perianth development.

As with other Urticaceae and allied families, the pseudomonomerous fruits of Poikilospermum are twocarpellate, the sterile carpel being more or less suppressed. A remarkable fruit feature in subgenus Ligulistigma is that the pericarp rib $\mathrm{r} 2$ formed by the suppressed carpel (which apparently represents its rudiment) is usually larger than the rib on the other, fertile carpel side (r1). It is reasonable to assume that the lobes of the largest rib in asymmetrical fruits of $P$. oblongifolium and $P$. scabrinervium are parts of an incompletely closed cavity representing a rudiment of the second loculus of the ovary, since such closed and incompletely closed pericarp cavities (represented by rib lobes only) have been observed in many Boehmeria species; furthermore, a second style was found in B. blumei (Kravtsova et al. 2000; Kravtsova 2009). In such Boehmeria species different collections of the same species vary considerably in the degree of expression of a carpel rudiment in fruits. Hitherto only a few Urticaceae genera have been observed to possess this rudiment (in the form of a wing or a swollen, often hollow rib), all belonging to the ancient (according to I. Friis 1989) tribes Boehmerieae (Boehmeria, Cypholophus) and Forsskaoleae (Forsskaolea). The presence of a similar rudiment in Poikilospermum (although belonging, according to the latest molecular data, to the younger tribe Urticeae) suggests that Poikilospermum, like Boehmeria, is one of the more ancient genera of the Urticaceae or at least has a position close to the basal representatives of the family. Within Poikilospermum, only in fruits of $P$. suaveolens is the r2:r1 ratio less than 1 , which may indicate that in this species the process of the reduction of a second carpel is complete and that $P$. suaveolens may be one of the younger species of the genus. The presence of this carpel rudiment correlates with some other, more primitive traits in $P$. scabrinervium and $P$. oblongifolium, namely a primitive form of fruiting perianth, pericarp and seed coat structural organisation (see below). The disappearance of a clearly expressed rudiment of a second carpel indicating a specialisation of basic fruit structures leads to the transformation from a morphology similar to those in P. scabrinervium (Fig. 14A) either to more or less equilateral fruit (certain species e.g. Fig. 14B) or to inequilateral fruit ( $P$. lanceolatum (Fig. 14C) where the style is displaced to the side of the suppressed carpel. In view of the discovery of prevailing very small fossil reproductive structures in early angiosperms (Friis et al. 2011) it should be noted, that the most primitive fruits within Poikilospermum are small with small-cellular pericarp.

The theory that straight fruits of Poikilospermum (treated within the Urticeae and within Urera) origi- 
nated through a reversion from oblique achenes (Wu et al. 2015) seems questionable. Carpological study of the tribe Urticeae (Kravtsova 2009) shows that both straight equilateral fruits of Urtica and oblique inequilateral fruits of Laportea are apparently derived; the oblique equilateral form of primitive fruits in certain Dendrocnide species, achene or pyrenarium, could in fact be the original fruit form in this tribe (Fig. 14D - F). The presence in certain Poikilospermum fruits of a rudiment of suppressed carpel as a large rib does not confirm the hypothesis of their origin in the tribe Urticeae through the above-mentioned reversion, since such a rudiment has not hitherto been observed in any other genus of the tribe Urticeae. However, it is possible that perhaps both pericarp ribs of the primitive, largest fruits in certain Dendrocnide species (e.g., in D. sinuata), which are thick wide, slightly two-lobed in section, provided with longitudinal furrows and dorsal vascular bundles, may represent such a rudiment analogous to some fruits of Boehmeria ramiflora where both swollen ribs of the pericarp represent the rudiments of a carpel. It is quite possible that this indicates an initial pistil of an unknown ancestor, formed, according to Bechtel (1921), by more than two carpels. Poikilospermum fruits are apparently primarily straight, and certain inequilateral fruits similar to the fruit of P. scabrinervium (Fig. 14A), with perpendicularly curved stigma, but with two dorsal vascular bundles, could give rise to the primitive oblique fruits in the Urticeae by the loss of the carpel rudiment and the style displacement (Fig. $14 \mathrm{~A} \rightarrow \mathrm{D}$ ).

(i) Possible evolutionary trends in fruiting perianth development

In subgenus Ligulistigma the primitive fruiting perianth state is perhaps a rather dense perianth similar to that of Poikilospermum scabrinervium: with undeveloped ribs and folds, weakly thickened lobe apices and large amounts of tannins and other solid inclusions in the tissues. Tannins are considered perhaps the most important protection against herbivores in angiosperms (Evert 2006). One of the trends in the evolution of fruiting perianth in Ligulistigma is the transition from tannin cells to other types of secretory structures, namely to terpenoid-containing mesophyll cells, apparently performing the same protective function ( $P$. naucleiflorum, $P$. oblongifolium, $P$. scortechinii). The evolution of fruits was accompanied in addition by the development of more enlarged, softer and fleshier parenchymatous fruiting perianth with slightly thickened cell walls, containing fewer solid inclusions (particularly in $P$. cordifolium, $P$. microstachys, $P$. peltatum and $P$. suaveolens), provided in certain species by numerous large swollen ribs and folds.
It is suggested here that a primitive feature of the fruiting perianth in subgenus Ligulistigma is the weakly swollen, hard, perianth lobe apex (Poikilospermum oblongifolium, $P$. scabrinervium, $P$. scortechinii). The more derived trait is a thicker and more swollen lobe apex which is juicy due to mucilaginous cavities (P. cordifolium, P. microstachys, P. naucleiflorum) or fleshy due to accrescent, small-cellular parenchyma (P. peltatum); the smaller cystolith size also contributes to the lobe apex being less hard. In this specialised condition the fruiting perianth apparently takes part in dissemination because it contributes to the fleshiness of the anthocarp. It is possible that the mucilage in the apices serves as lubrication when the fruit is squeezed. The mechanism of lobe apex transformation is seen when an intermediate structure is observed in $P$. cordifolium: mucilaginous cavities, neither numerous nor very large, embedded in welldeveloped parenchyma become more numerous, larger and occupy almost all the apex volume in the other listed species.

(ii) Possible evolutionary trends in pericarp development

In subgenus Ligulistigma some possible evolutionary trends in pericarp development may be proposed such as the decrease of tannins in tissues (as in the fruiting perianth and seed coat) and the expansion of the mucilaginous zone. Initially the continuous tannin-containing, middle mesocarp zone, transforms via parenchymatisation and cell differentiation to a mucilaginous sparse-tannin zone, consisting of alternate cells of different types i.e. mucilage cells, tannin cells and parenchyma cells with irregularlythickened porous walls, or sclereids. Consequently, mucilage cells are distributed deeper within the pericarp layer. Scattered (sometimes forming a net), non-mucilaginous mechanical elements (parenchymatous or sclerenchymatous, with or without tannins) replace the continuous layer of hard tannin cells. The presence of parenchyma cells with porous walls in the mucilaginous mesocarp indicates the development here of a perfect hydrocytic system, directed apparently towards aiding water absorption and retention in the pericarp, as has been suggested previously for the Urticaceae (Yakovleva \& Kravtsova 1999). Pericarp transformation also involves exocarp structure: the outer tangential cell walls become thinner such that the exocarp may easily break.

This evolutionary process may be represented by the diagram (Fig. 15A - F). Two levels of pericarp structural organisation are thus seen in subgenus Ligulistigma: (i) with mucilage cells in one (outer) mesocarp layer, (ii) with mucilage cells in two or three mesocarp layers. Within both groups, transformation towards the mechanical strengthening of the pericarp can be seen (Fig. 15: $\mathrm{A} \rightarrow \mathrm{B} ; \mathrm{C} \rightarrow \mathrm{E} ; \mathrm{C} \rightarrow \mathrm{F}$ ) occurring via 


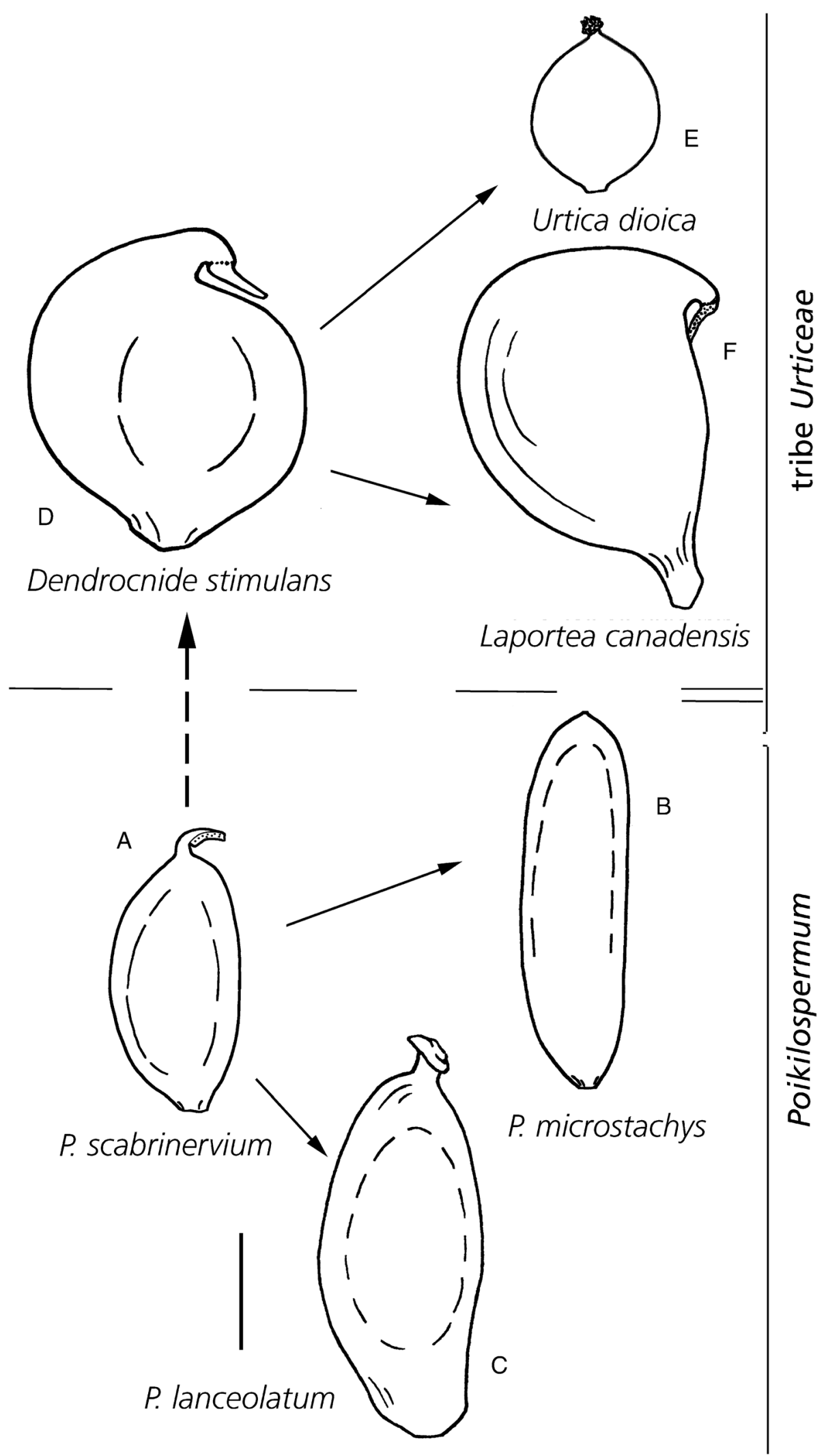

Fig. 14. Possible trends of fruit evolution in Poikilospermum and tribe Urticeae. A - C Poikilospermum; D - F tribe Urticeae. Scalebar $=1000 \mu \mathrm{m}$ 
sclereid development in the mesocarp of Poikilospermum scortechinii (Fig. 15B), P. lanceolatum (Fig. 15E) and $P$. naucleiflorum (Fig. 15F). The presence of the remnants of the second carpel in $P$. oblongifolium and $P$. scabrinervium (as discussed above) gives support to the suggestion that pericarp structure is the most primitive in these species.

In subgenus Poikilospermum all species studied have the lower level of pericarp structural organisation. The primitive trait is the weak development of the mucilage cells in the pericarp, disposed mostly in one (outer) mesocarp layer or in more or less isolated cavities. Poikilospermum paxianum is more progressive in this respect. In $P$. inaequale the pericarp is similar to the primitive pericarp of $P$. scabrinervium with a continuous tanniniferous layer in the mesocarp. This structure may then be close to a primitive pericarp structure for the whole genus. The pericarp of $P$. amboinense with a simplified mesocarp and that of $P$. acuminatum with unique composition of pericarp tubercles are apparently derived.

(iii) Possible evolutionary trends in seed coat In subgenus Ligulistigma the reduction of the seed coat, from less simplified in Poikilospermum scabrinervium, $P$. scortechinii and $P$. tangaum Clemens 29769, is represented in Fig. $15(\mathrm{G} \rightarrow \mathrm{H})$ moving towards a more simplified structure in P. microstachys. It is accompanied, as in tribe Urticeae (Kravtsova 2003) by a decrease in tannins in its layers, a reduction of ribs, the development of uniform long linear exotesta cells, a transition from reticulate primary sculpture to a somewhat striate one and the loosening of the endotesta. In several species ( $P$. microstachys, $P$. naucleiflorum) a more ordered seed coat structure appears where cells of exo- and endotesta are elongated mainly in mutually perpendicular directions. This derived seed coat state gives the seed its mechanical strength (Takaso \& Tobe 1990).

In subgenus Poikilospermum all species studied display a more derived and perforated seed coat structure.

(iv) Possible evolutionary trends in fruit characters connected with dissemination and germination

The evolutionary changes in fruits in subgenus Ligulistigma as described above result in a more soft and juicy fruit with increased mucilage content. Such mucilage production is considered to be important for zoochory, both epizoochory (e.g., van der Pijl 1972; Grubert 1974) and endozoochory. For example, external mucilage production in small fruits of Cecropia was concluded to facilitate endozoochory, namely their passage along the digestive tract of animals (Lobova et al. 2003). It has also been noted that small fruits of
Poikilospermum may be carried by birds (epizoochory) (Chew 1963; Berg 1983). C. C. Berg (1983, 1989) has suggested that this phenomenon could be connected with a (hemi-) epiphytic habit; birds spread the diaspores on high trees and the plants then begin their life as epiphytes. The mechanism for attachment of diaspores to animaldisseminators, ensuring epizoochory, is seen to be very conservative in Poikilospermum similar to that of fruits almost lacking accessory envelopes and for anthocarpous fruits. The ejection (squeezing) of fruits covered with mucilage out of the fruiting perianth tube in subgenus Ligulistigma species may be regarded as evolutionary repetition, i.e. repetition of previous dissemination behaviour and the imitation of a primitive fruit state in subgenus Poikilospermum. Due to enveloping mucilage, fruits in both subgenera are sticky and perhaps more attractive to animals. Due to a thinning of the outer tangential walls in the exocarp of advanced fruits, even a light touch of the animal-disseminator to the surface may cause the destruction of the membranous exocarp and allow mucilage to escape.

The results obtained allow some speculation concerning the mechanism of fruit ejection. According to observations by G. Bargagli-Petrucci (1902), at fruit maturity the inner perianth surface becomes mucilaginous, detaches from adjacent tissues and then inflates, which results in the ejection of the fruit. C. C. Berg $(1977,1978)$ further added that the fruit is squeezed out of the thickened perianth base surrounded by mucilage from the mucilagecontaining mesocarp. In the present study the observations by Bargagli-Petrucci were not confirmed. Several new details, and another explanation of possible mechanism of fruit ejection is suggested: as a result of mucilage swelling the membranous exocarp may partly break allowing mucilage to flow out into the perianth tube. A thickened perianth base encompasses the stipe, in many species of subgenus Ligulistigma almost completely consisting of mucilage cells; mucilage cells are present in the axial flower part and also within the pedicel of Poikilospermum peltatum. The stipe, which is only connected to the perianth by a narrow ring of compressed parenchyma (see arrows in Fig. 10F), becomes easily detached from it and from the receptacle when the mucilage swells. It is suggested that the separated fruit is squeezed from the perianth tube due to a large amount of swelling mucilage, filling up the tube base. The hard, thickened base of the fruiting perianth determines the direction of the ejection of the fruit.

Fruit dehiscence by two valves in Poikilospermum has previously been recorded in botanical literature (Trécul 1847; Chen et al. 2003). However, the 


\section{Pericarp}

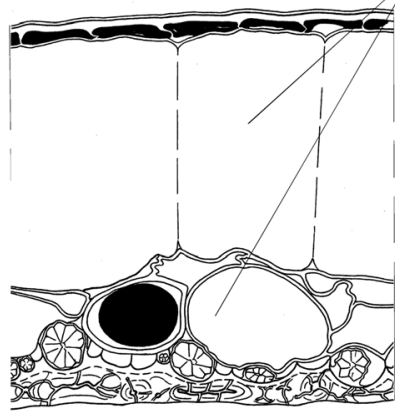

$\mathrm{mc}$

non mc

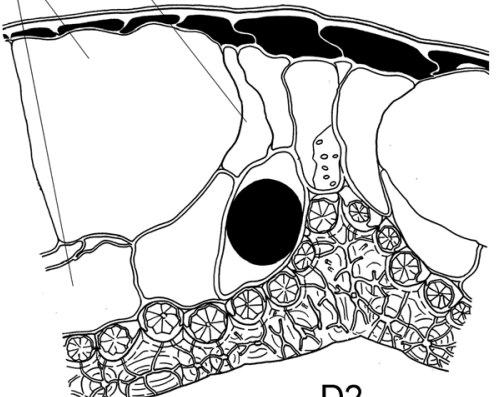

D1

$\uparrow$

D2
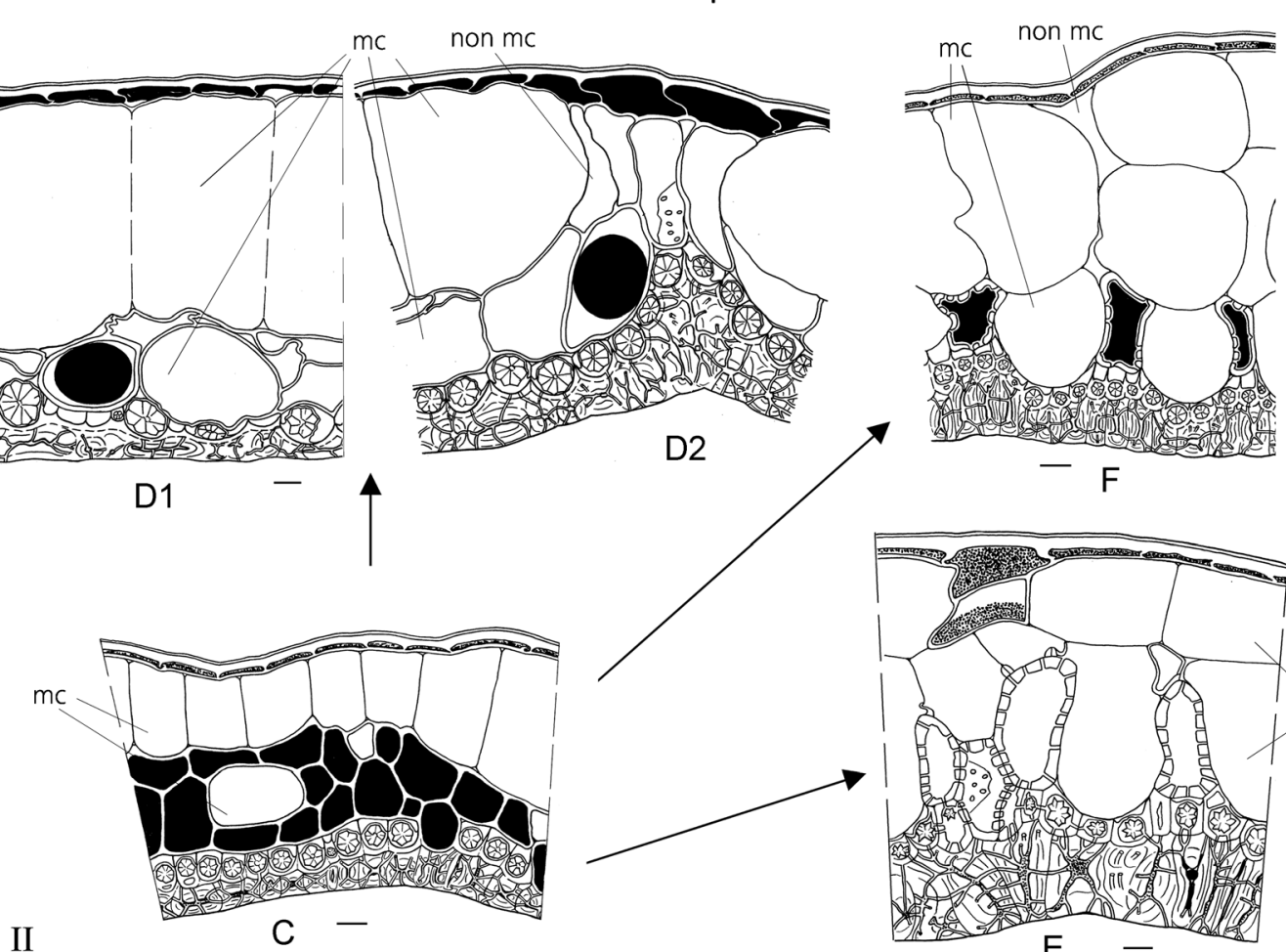

II

C -
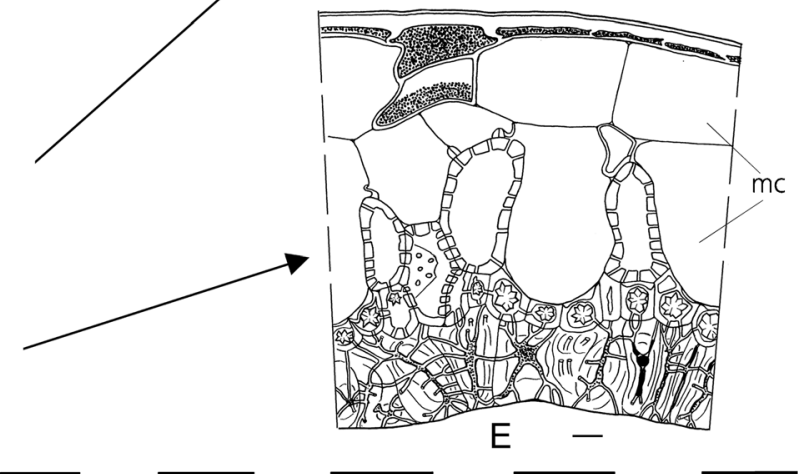

I
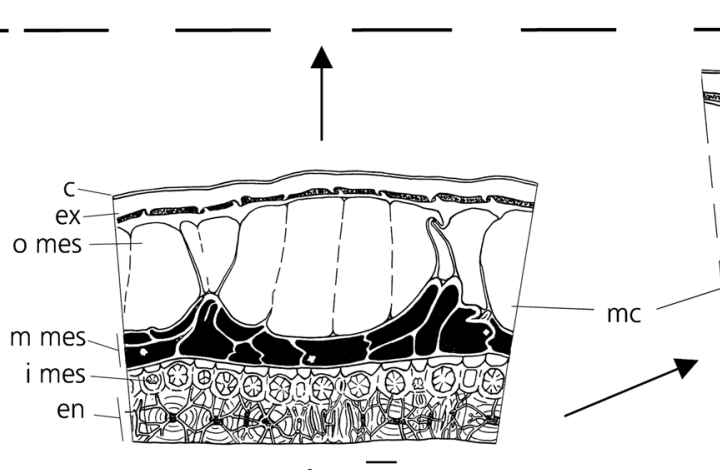

A

Seed coat

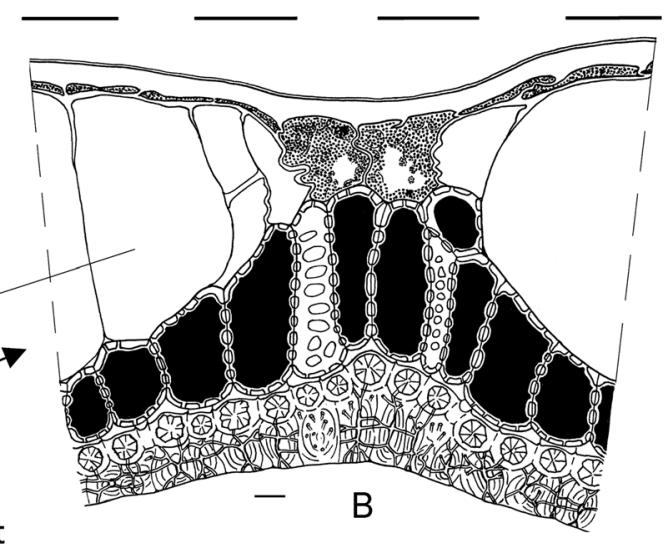

$\mathrm{H}$

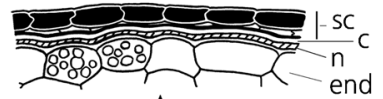

G

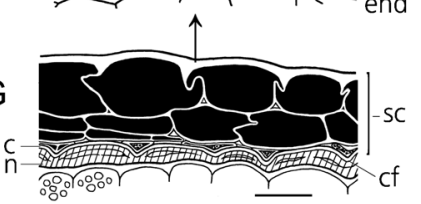

Fig. 15. Pericarp and seed coat evolution; Poikilospermum subgenus Ligulistigma. A - F pericarp. A continuous tannin-containing middle mesocarp zone in $P$. scabrinervium; B $P$. scortechinii; $C$ interrupted tannin-containing middle mesocarp zone in $P$. cordifolium; D sparse tanniniferous tannin-containing middle mesocarp zone in P. microstachys: D1 portion between tubercles, D2 in tubercle; E sparse tanniniferous zone in $P$. lanceolatum; F sparse tanniniferous zone in $P$. naucleiflorum; G, H seed coat. G P. scabrinervium; H P. microstachys; I, II evolutionary levels; c cuticle; cf cuticle fold; en endocarp; end endosperm; ex exocarp; i mes inner mesocarp zone; mc mucilage cell; $\mathrm{m}$ mes middle mesocarp zone; $\mathrm{n}$ nucellus; non mc cell without mucilage; o mes outer mesocarp zone; sc seed coat. Scalebars $=10 \mu \mathrm{m}$ 
authors are not convinced that it is true dehiscence but may rather be a mechanism to aid germination by allowing a more easy escape of the radicle during germination, since this study was unable to record the splitting of the fruit uniformly in any of the species studied and hence strongly indicates that it may simply be an artefact of different herbarium drying or storage techniques in individual fruit specimens. However, additional field observations are needed since it can be seen that the anatomical prerequisite of such easy apical splitting does exist due to the special structure of the pericarp ribs near the fruit apex (deep slit-like internal grooves). This structure is not found in other genera of the Urticaceae. This ability of the fruit to split at the apex is best marked in $P$. microstachys but absent in the primitive fruits of $P$. scabrinervium and $P$. oblongifolium and appears to have gradually evolved within subgenus Ligulistigma.

\section{Comparison with and relationships with other} genera of Urticaceae

Although Urera has been considered to be the closest relative of Poikilospermum according to recent molecular data (Wu et al. 2013; Kim et al. 2015), our carpological research casts doubt on this and suggests Dendrocnide as anatomically the closest. An argument for Urera from wood anatomy is incorrect (Kim et al. 2015); Poikilospermum and Nothocnide show fibre dimorphism, according to Bonsen \& ter Welle (1984), but Urera does not. Poikilospermum however is very similar to the climbing species of Urera in wood anatomy. (i) Pericarp

Within the Urticeae, only several Dendrocnide species (21 species studied out of c. 36) have the fruit type characteristic for Poikilospermum, a pyrenarium, with membranous exocarp and mucilaginous mesocarp (Fig. 16A, B). Their pericarp has a primitive structure: weakly histologically differentiated or with uncertain differentiation of layers; the crystal layer is absent, only sporadic cells with raphides being present. In all Urera species studied (7 species out of c. 35: Kravtsova 2009) the fruit type is an achene with the mucilaginous exocarp, one-layered or comprising several outer layers making up a mucilagecontaining exo-mesocarp (e.g., U. baccifera - Fig. 16C, D). The hydrocytic system location (in both pericarp layers within the exo-mesocarp) differs from that in Poikilospermum where hydrocytic elements develop only in the mesocarp.

(ii) Seed coat

In subgenus Poikilospermum there is a micromorphological feature, namely a perforation type, similar to that shown by many taxa of tribe Urticeae, but this character shows a homoplasy (Kravtsova 2003). The seed coat inner structure in Poikilospermum is similar to the type Urtica, variant Dendrocnide because of its structureless endotegmen. The closest resemblance in seed coat structure is again with genus Dendrocnide (rather than Urera), since it is the only other where endotesta cells sometimes do not exhibit strict transverse orientation and their shape may vary within a seed.

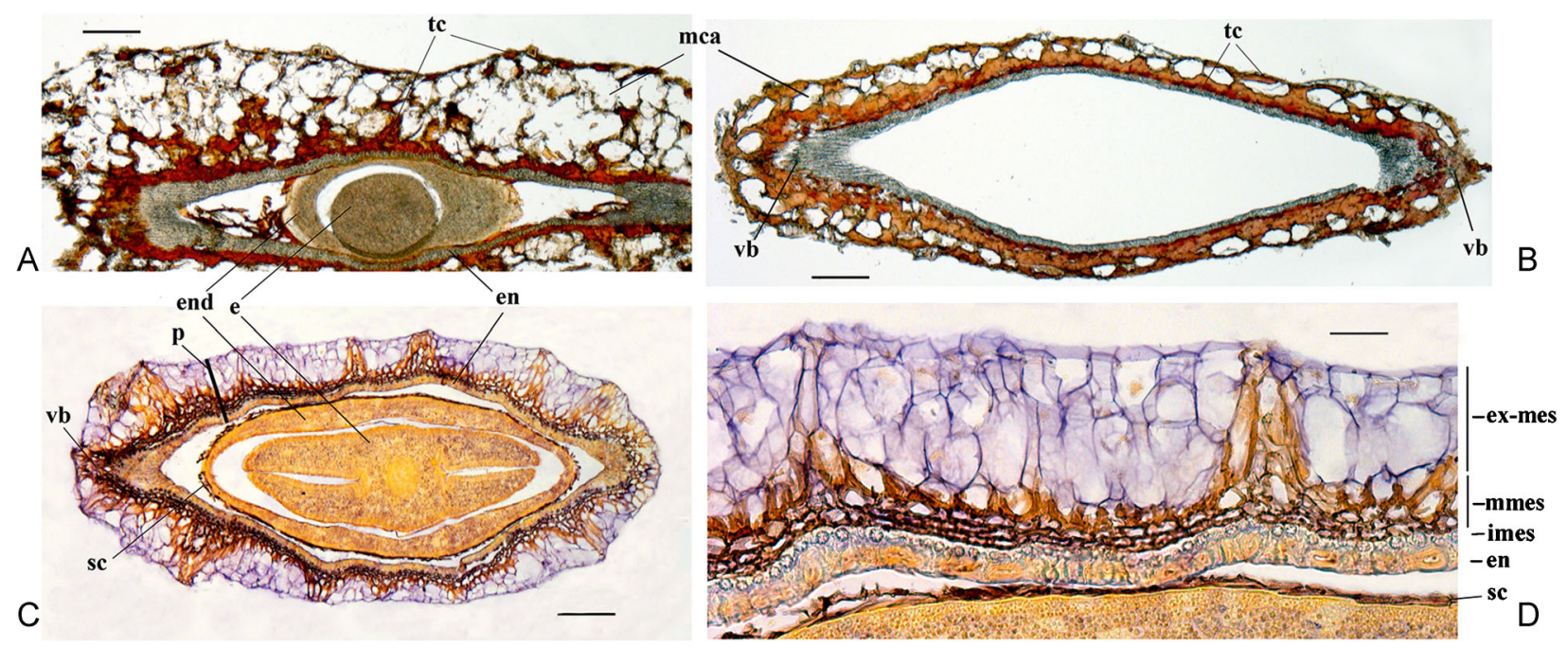

Fig. 16. Fruit and fruit wall in cross section in Dendrocnide and Urera. A Dendrocnide meyeniana f. meyeniana; B D. stimulans; C, D Urera baccifera: fruit and portion of cross section in lateral fruit side respectively; e embryo; en endocarp; end endosperm; ex-mes exo-mesocarp; i mes innermost mesocarp layer; mca mucilaginous cavity; m mes middle mesocarp zone; $p$ pericarp; sc seed coat; tc tannin cell; vb vascular bundle. Scalebars: $A-C=200 \mu \mathrm{m}, \mathrm{D}=50 \mu \mathrm{m}$ 


\section{Traits unusual within Urticaceae}

Poikilospermum has a fruit-type which is rare for the Urticaceae, namely a pyrenarium, and is notable for its unusual combination of primitive and advanced characteristics. Although the fruit retains a clearly discernible rudiment of a sterile carpel, the pericarp structure and dissemination behaviour are more specialised than in those Dendrocnide species with drupaceous fruits. As discussed above under possible evolutionary trends, other genera of the tribe Urticeae lack such a rudiment, unless the large flat fruit ribs of certain Dendrocnide species represent such a rudiment.

Kravtsova et al. (2003) noted that the seed coat feature discussed above, namely considerable diversity of endotesta cell shape even within a single seed, is characteristic for the Moraceae. Moraceous traits have previously been seen in vegetative morphology and this additional finding reinforces the observation that Poikilospermum occupies a somewhat intermediate position between the two families.

\section{Concluding Remarks}

It is noteworthy that this study has highlighted a disparity in the position of Poikilospermum within Urticaceae. The molecular data has strongly indicated it as nested within Urera, but the present study indicates Dendrocnide as anatomically the closest to Poikilospermum. Despite its inclusion in tribe Urticeae, fruit structure also indicates it may in fact be one of the more ancient genera of Urticaceae. The fact that both primitive and derived species can be found in both subgenera indicates that the morphological and anatomical features which divide the subgenera do not do so along ancestral lines.

Fruit anatomical characters are informative both in arranging informal groupings which are to some extent helpful in reinforcing the findings of gross morphology and in reaffirming the nature of this genus as somewhat intermediate between two families.

Having observed structural peculiarities with the potential to facilitate the splitting of the fruit along its apex, this study highlights the need for better field observations to determine the exact mechanism by which the dissemination occurs.

\section{Acknowledgements}

The authors appreciate the help of the curators of Herbaria K, L and LE from which material was received, and are grateful to L. A. Kartseva, the head of scanning electron microscopy branch of the Core Facility Center in LE for technical assistance in SEM studies. The staff from the Laboratory of Plant Anatomy and Morphology in LE are thanked for preparing some material for investigation and assistance in photography. The present study was carried out within the framework of the institutional research project (no. AAAA-A18-1180316900084-9) of the Komarov Botanical Institute RAS. T. Kravtsova participated in this study in a project supported by the Russian Foundation for Basic Research under grant 13-04-0852.

Open Access This article is distributed under the terms of the Creative Commons Attribution 4.0 International License (http://creativecommons.org/ licenses/by/4.0/), which permits unrestricted use, distribution, and reproduction in any medium, provided you give appropriate credit to the original author(s) and the source, provide a link to the Creative Commons license, and indicate if changes were made.

\section{References}

Bargagli-Petrucci, G. (1902). Revista del genere Conocephalus Bl. Nuovo Giorn. Bot. Ital. n.s. 9: 213 230.

Barthlott, W. (1981). Epidermal and seed surface characters of plants: systematic applicability and some evolutionary aspects. Nord. J. Bot. 1: $345-355$. \& Ehler, N. (1977). Raster-Elektronenmikroskopie der Epidermisoberflachen von Spermatophyten. Trop. Subtrop. Pflanzenwelt 19: 367 - 467.

Bechtel, A. R. (1921). The floral anatomy of the Urticales. Amer. J. Bot. 8: $386-410$.

Berg, C. C. (1977). Urticales, their differentiation and systematic position. Pl. Syst. Evol. Suppl. 1: 349 - 374. (1978). Cecropiaceae - a new family of the Urticales. Taxon 27(1): 39 - 44.

(1983). Dispersal and distribution in the Urticales - an outline. In: K. Kubitzki (ed.), Dispersal and Distribution. Sonderb. Naturwiss. Vereins Hamburg 7: $219-229$.

(1989). Systematics and phylogeny of the Urticales. In: P. R. Crane \& S. Blackmore (eds), Evolution, systematics, and fossil history of the Hamamelidae 2: 193 220. Systematics Association Special Volume 40, Oxford Science Publications; Clarendon Press, Oxford; Oxford University Press, New York.

Bigalke, H. (1933). Die Blattspodogramme der Urticaceae und ihre Verwendbarkeit für die Systematik. Beitr. Biol. Pflanzen 21: 1 - 58.

Bobrov, A. V. F. C., Melikyan, A. P. \& Romanov, M. S. (2009). Morphogenesis of fruits of Magnoliophyta. Libricom, Moscow [in Russian].

Bonsen, K. J. \& ter Welle, B. J. H. (1984). Systematic wood anatomy and affinities of the Urticaceae. Bot. Jahrb. Syst. 105: 49 - 71.

Chen, C.-J., Lin, Qi, Friis, I., Wilmot-Dear, C. M. \& Monro, A. K. (2003). Urticaceae, pp. 76 - 189. In: Z. Wu, P. H. Raven \& D. Y. Hong (eds), Flora of China. 5: Ulmaceae through Basellaceae. Science Press, Beijing. 
Chew, W.-L. (1963). Florae Malesianae Precursores-IV. A revision of the genus Poikilospermum (Urticaceae). Gard. Bull. Singapore 20: 1 - 103.

Corner, E. J. H. (1976). The seeds of dicotyledons Vol. 1. Cambridge University Press, Cambridge, New York.

David, R. \& Carde, J.-P. (1964). Coloration differentiele des inclusions lipidique et terpeniques des pseudophilles du pin maritime au moyen du reactif nadi. Compt. Rend. Acad. Sci. 258: 1338 1340.

Deng, T., Kim, C., Zhang, D.-G., Zhang, J.-W., Li, Z.M., Nie, Z.-L. \& Sun, H. (2013). Zhengyia shennongensis: A new bulbiliferous genus and species of the nettle family (Urticaceae) from central China exhibiting parallel evolution of the bulbil trait. Taxon 62(1): 89 - 99.

Eckardt, T. (1937). Untersuchungen über Morphologie, Entwicklungsgeschichte und systematische bedeutung des pseudomonomeren Gynoeceums. Nova Acta Leop. 5(26): 1 - 112.

Evert, R. F. (2006). Esau's Plant anatomy. Meristems, cells, and tissues of plant body, their structure, function, and development. 3rd ed. J. Wiley \& Sons, Hoboken.

Friis, E. M., Crane, P. R. \& Pedersen, K. R. (2011). Early flowers and angiosperm evolution. Cambridge University Press, Cambridge.

Friis, I (1989). The Urticaceae a systematic review. In: P. R. Crane \& S. Blackmore (eds), Evolution, systematics, and fossil history of the Hamamelidae. 2: 285 -308. Systematics Association Special Volume 40, Oxford Science Publications; Clarendon Press, Oxford; Oxford University Press, New York.

(1993). Urticaceae, pp. 612 - 630. In: K. Kubitzki, J. G. Rohwer \& V. Bittrich (eds), The families and genera of vascular plants, Vol. 2, Flowering plants: Dicotyledons; Magnoliid, Hamamelid and Caryophyllid families. Springer, Berlin.

Grubert, M. (1974). Studies of the distribution of myxospermy among seeds and fruits of Angiospermae and its ecological importance. Acta Biol. Venez. 8: 315 - 551.

Grudzinskaya, I. A. (1980). The family Cecropiaceae. In: Al. A. Fedorov (ed.), Life of Plants $M$. Prosveschenie. 5(I): 284 - 289 [in Russian].

Hadiah, J. T., Conn, B. J. \& Quinn, C. J. (2008). Infrafamilial phylogeny of Urticaceae, using chloroplast sequence data. Austral. Syst. Bot. 21: 375 - 385.

Kim, C., Deng, T., Chase, M., Zhang, D.-G., Nie, Z.-L. \& Sun, H. (2015). Generic phylogeny and character evolution in Urticeae (Urticaceae) inferred from nuclear and plastid DNA regions. Taxon 64(1): 65 - 78 .

Kravtsova, T. I. (1995). Pericarp and seed coat structure in the Cecropiaceae (Urticales). Bot. Zhurn. (Moscow Ẽ St. Petersburg) 80 (5): 1 - 14 [in Russian].

(2001). Pericarp structure in the tribe Urticeae (Urticaceae) in relation to its systematics. Bot.
Zhurn. (Moscow Ẽ St. Petersburg) 86 (11): 49 - 72 [in Russian].

(2003). Seed coat structure in the Urticaceae and relation of the Urticales. Bot. Zhurn. (Moscow Ev St. Petersburg) 88 (11): 11 - 41 [in Russian].

(2009). Comparative carpology of the Urticaceae Juss. KMK Scientific Press, Moscow [in Russian].

Berg, C. C. \& Zhinkina, N. A. (2011). Fruit structure in members of Poikilospermum (Cecropiaceae), pp. 129 - 133. In: Carpology and reproductive biology of higher plants. Proceedings of the Russian conference with international participation dedicated to the memory of Professor A. P. Melikyan (18 - 19 October 2011, Moscow). Astra-Poligraphia Ltd, Moscow [in Russian].

, Friis, I. \& Wilmot-Dear, C. M. (2000). Morphology and anatomy of fruits in New World Boehmeria in relation to taxonomy. Kew Bull. 55: 43 - 62 . \& _ (2003). Morphology and anatomy of fruits in Pouzolzia (Urticaceae) in relation to taxonomy. Kew Bull. 58: 297 - 327.

Lobova, T. A., Mori, S. A., Blanchard, F., Peckham, H. \& Charles-Dominique, P. (2003). Cecropia as a food for bats in French Guiana and significance of fruit structure in seed dispersal and longevity. Amer. J. Bot. 90 (3): 388 - 403.

Monro, A. K. (2006). The revision of species-rich genera: a phylogenetic framework for the strategic revision of Pilea (Urticaceae) based on cpDNA, nrDNA, and morphology. Amer. J. Bot. 93(3): 426 441.

Murley, M. R. (1951). Seeds of the Cruciferae of Northeastern North America. Amer. Midl. Naturalist 46: $1-81$.

Prozina, M. N. (1960). Botanical microtechniques. Vysschaya Schkola, Moscow [in Russian]

Roth, I. (1977). Fruits of angiosperms. Encyclopedia of Plant Anatomy 10 (1). G. Borntraeger, Berlin.

Spjut, R. W. (1994). A systematic treatment of fruit types. Mem. New York Bot. Gard. 70: 1 - 182.

Takaso, T. \& Tobe, H. (1990). Seed coat morphology and evolution in Celtidaceae and Ulmaceae (Urticales). Bot. Mag. (Tokyo) 103(1069): 25 - 41.

Trécul, M. A. (1847). Mémoire sur la famille des Artocarpées. Ann. Sci. Nat., Bot. Ser. 3. 8: 38 157.

van der Pijl, L. (1972). Principles of dispersal in higher plants. Springer-Verlag, Berlin.

Wang, W. T. \& Chen, C. J. (1995). Urticaceae, pp. 1 404. In: Flora Reipublicae Popularis Sinicae. Science Press, Bejing.

Weddell, H. A. (1856 - 1857). Monographie de la famille des Urticacées. Arch. Mus. Hist. Nat. 9: 1 592.

Werker, E. (1997). Seed anatomy. Encyclopedia of plant anatomy. Bd 10. Teil 3. Gebruder Borntraeger, Berlin. 
Winkler, H. (1922). Die Urticaceen Papuasiens. Bot. Jahrb. Syst. 57: 595 - 603.

Wu, Z.-Y., Monro, A., Milne, R. I., Wang, H., Yi, T.-S., Liu, J. \& Li, D.-Z. (2013). Molecular phylogeny of the nettle family (Urticaceae) inferred from multiple loci of three genomes and extensive generic sampling. Molec. Phylogenet. Evol. 69: 814 - 827.

, Milne, R. I., Chen, C.-J., Liu, J., Wang, H. \& Li, D.-Z. (2015). Ancestral state reconstruction reveals rampant homoplasy of diagnostic morphological characters in Urticaceae, conflicting with current classification schemes. PLoS ONE 10(11): e0141821. https://doi.org/10.1371/journal.pone.0141821.

Yakovleva, O. V. \& Kravtsova, T. I. (1999). Pericarp cell ultrastructure in Urtica dioica (Urticaceae). Bot. Zhum. (Moscow Ẽ St. Petersburg) 84 (7): 33 - 41 [in Russian].

\section{Publisher's Note}

Springer Nature remains neutral with regard to jurisdictional claims in published maps and institutional affiliations. 